\title{
Lipid-Lowering Effects of Ethyl 2-Phenacyl-3-aryl-1H-pyrrole- 4-carboxylates in Rodents
}

Justin M. Holub ${ }^{1}$, Kathy O'Toole-Colin ${ }^{1}$, Adam Getzel ${ }^{1}$, Anthony Argenti ${ }^{1}$, Michael A. Evans ${ }^{1}$, Daniel C. Smith ${ }^{1}$, Gerard A. Dalglish ${ }^{1}$, Shahzad Rifat ${ }^{1}$, Donna L. Wilson ${ }^{1}$, Brett M. Taylor ${ }^{1}$, Ulander Miott ${ }^{1}$, Josephine Glersaye ${ }^{1}$, Kam Suet Lam ${ }^{1}$, Bryan J. McCranor ${ }^{1}$, Joshua D. Berkowitz $^{1}$, Robert B. Miller ${ }^{2}$, John R. Lukens ${ }^{2}$, Keith Krumpe ${ }^{3}$, John T. Gupton ${ }^{2}$ and Bruce S. Burnham ${ }^{1, *}$

${ }^{1}$ Department of Chemistry and Biochemistry, Rider University, 2083 Lawrenceville Rd., Lawrenceville, NJ 08648, U.S.A.

2 Department of Chemistry, University of Richmond, Richmond, VA 23173, U.S.A.

${ }^{3}$ Department of Chemistry, UNC-Asheville, One University Heights, Asheville, NC 28801, U.S.A.

* Author to whom correspondence should be addressed. Tel: +1 609-896-5207; fax: +1 609-895-5782; e-mail: bburnham@rider.edu

Received: 23 January 2004; in revised form: 28 January 2004 / Accepted 29 January 2004 / Published: 28 February 2004

\begin{abstract}
A series of substituted 2-phenacyl-3-phenyl-1H-pyrrole-4-carboxylates were prepared from substituted acetophenones in 6 steps. The final condensations between a chloroenal and an aminoketone were carried out under neutral conditions in parallel to yield the series listed below. Selected pyrrole derivatives proved to be potent hypolipidemic agents lowering serum triglyceride concentrations in CF-1 male mice after 14 days of I.P. administration. One agent orally lowered serum cholesterol in Sprague-Dawley male rats at $2 \mathrm{mg} / \mathrm{kg} /$ day after 14 days. The agents demonstrated a lowering of mouse serum LDLcholesterol levels and selected compounds showed an elevation of serum HDL-cholesterol levels. The cholesterol concentrations in the liver were raised while the cholesterol and triglyceride contents of the aorta were significantly lowered by the selected trisubstituted pyrrole.
\end{abstract}

Keywords: Pyrrole, hypolipidemia, cholesterol, triglyceride 


\section{Introduction}

In recent years, polysubstituted pyrroles have shown interesting biological properties. 2,4Disubstituted brominated pyrroles, which are brominated at positions 3 and 5 along with 2,3,4trisubstituted pyrroles have demonstrated potent cytotoxic activity in vitro against a variety of murine and human suspended and solid tumor models [1-4]. Also, pentasubstituted pyrroles have proven to be potent hypocholesterolemic agents through the inhibition of HMG-CoA reductase activity, a key enzyme in the de novo synthesis of cholesterol [5-11]. Two of these pyrroles, atorvastatin and fluvastatin (Figure 1), are in clinical use today for the treatment of hyperlipidemias [12]. It is not unprecedented for compounds to exhibit hypolipidemic in addition to other pharmacological properties. The HMG-CoA reductase inhibitors have recently demonstrated various pleiotropic effects including cardiovascular protective effects independent of hypercholesterolemia [11-13], antiinflammatory effects [14-16] and a decreased risk of the development of Alzheimer's disease [17-20]. Compactin, also an HMG-CoA reductase inhibitor, has been shown to inhibit the growth of murine L929 cells [21]. Likewise, a number of amine-boranes [22-28], 2,3-dihydrophthalazine-1,4-diones [29], sesquiterpene lactones [30], and 1,2,4-triazolidine-3,5-diones [31] have demonstrated such crossover between cytotoxic and hypolipidemic properties.

Figure 1. Structures of the clinically used pyrrole-containing hypolipidemic agents atorvastatin $\left(\right.$ Lipitor $\left.^{\mathrm{R}}\right)$ and fluvastatin $\left(\mathrm{Lescol}^{\mathrm{R}}\right)$.
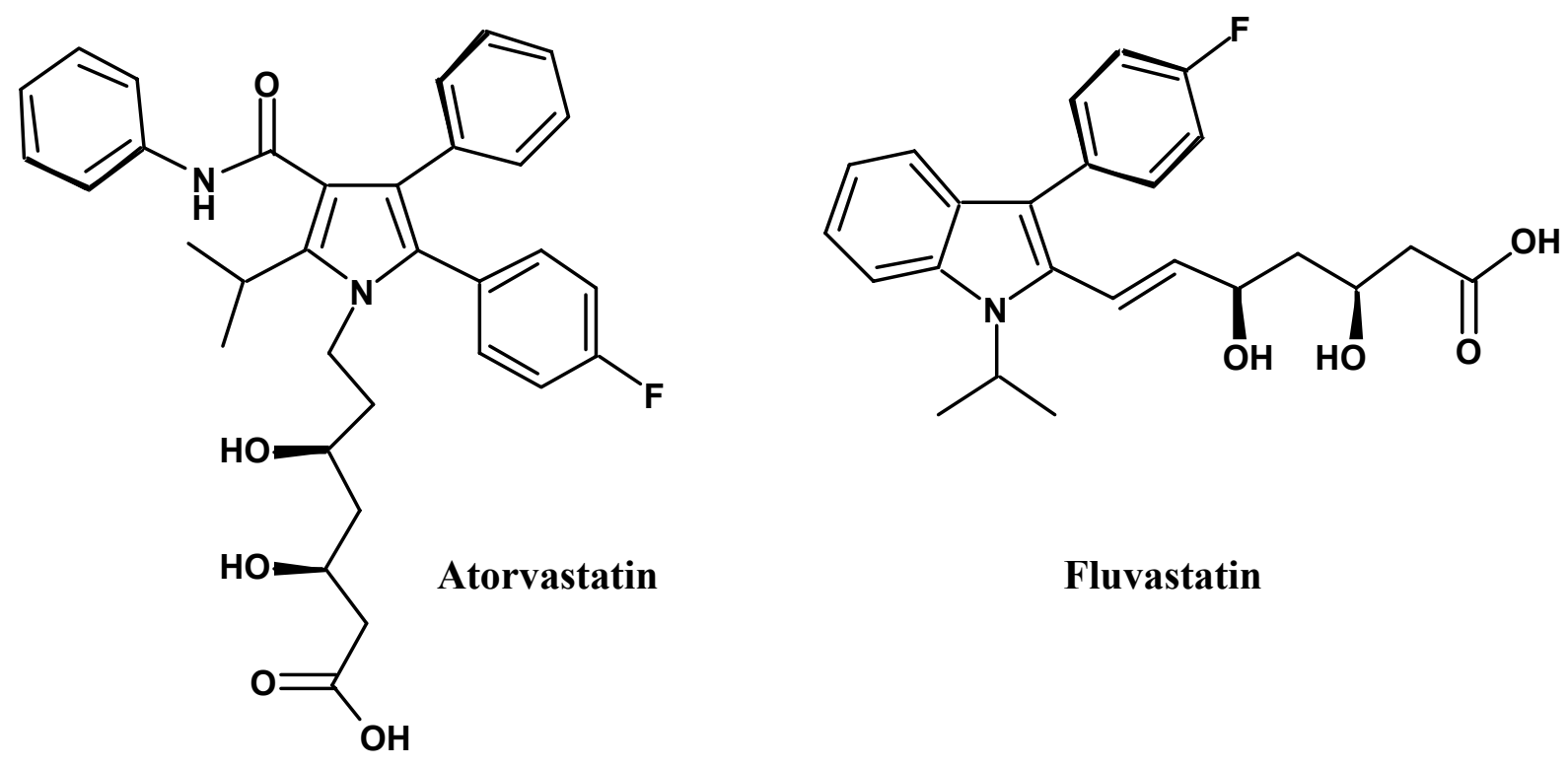

Given the importance of correcting hyperlipidemias to improve the risks of developing cardiovascular disease and the toxic effects of the $\mathrm{HMG}-\mathrm{CoA}$ reductase inhibitors such as liver damage [12], the search for new lipid-lowering compounds is of interest. As part of our screening program evaluating the biological effects of pyrroles, we report the synthesis and preliminary lipid-lowering effects of 2,3,4-trisubstituted pyrroles in rodents. An initial examination of the structure and lipid- 
lowering profiles of these new pyrroles compared to the atorvastatin and fluvastatin shows that the 2,3,4-trisubstituted pyrroles may represent a new class of hypolipidemic agents.

\section{Chemistry}

The regioselective synthesis of 2,3,4-trisubstituted pyrroles from chloroenals has recently been reported by Gupton, et. al [1-4,32,33]. The convergent synthesis generates acceptable yields through the final condensation, however with the aid of the XT reactor (Mettler-Toledo AutoChem), up to six derivatives were easily prepared under a dry, inert atmosphere and constant temperature. The yields reported represent the final recrystallized amounts of analytically pure compounds isolated for use in the bioassays and do not represent the overall chemical yields for the reactions.

Figure 2: Preparation of the $\beta$-chloroenals from acetophenones

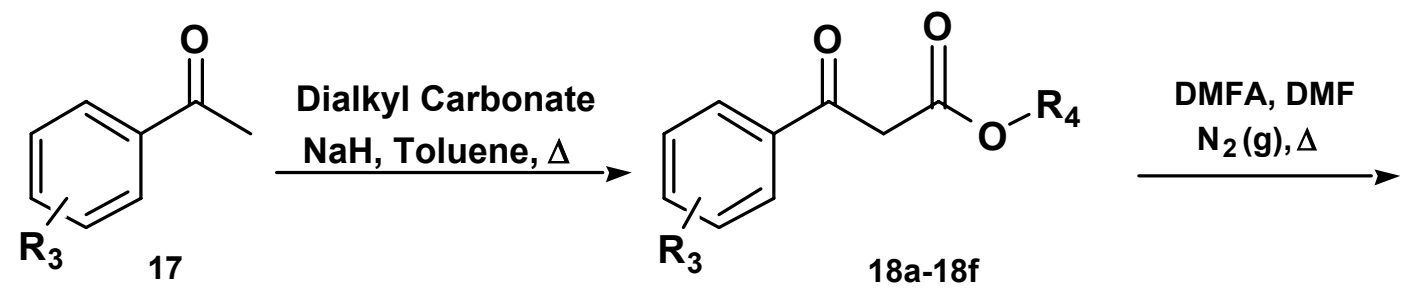<smiles>[R3]OC(=O)C(=CN(C)C)C(=O)O[R]</smiles>

$\left(\mathrm{R}_{3}=4^{\prime}-\mathrm{Cl}, \mathrm{R}_{4}=-\mathrm{CH}_{2} \mathrm{CH}_{3}\right.$ [a]; $\mathrm{R}_{3}=4^{\prime}-\mathrm{Br}, \mathrm{R}_{4}=-\mathrm{CH}_{2} \mathrm{CH}_{3}$ [b], $\mathrm{R}_{3}=3^{\prime}-\mathrm{Cl}, \mathrm{R}_{4}=-\mathrm{CH}_{2} \mathrm{CH}_{3}$ [c], $\mathrm{R}_{3}=4^{\prime}-\mathrm{CH}_{3}, \mathrm{R}_{4}=-\mathrm{CH}_{2} \mathrm{CH}_{3}$ [d], $\mathrm{R}_{3}=4^{\prime}-\mathrm{F}, \mathrm{R}_{4}=-\mathrm{CH}_{2} \mathrm{CH}_{3}$ [e]; $\mathrm{R}_{3}=4^{\prime}-\mathrm{OCH}_{3}, \mathrm{R}_{4}=-$ $\left.\mathrm{CH}_{3}[\mathrm{f}]\right)$.

Figure 3: Preparation of the salt of the $\alpha$-aminoketones from 2-bromoacetophenones

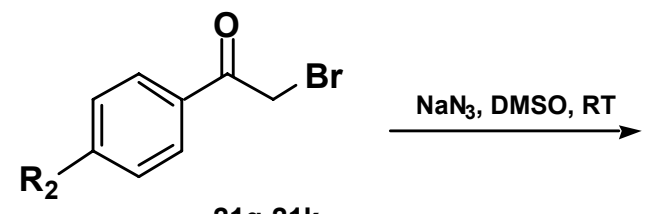

21g-21k<smiles>[R2]c1ccc(C(=O)CN)cc1</smiles>

22g-22k<smiles>[R2]c1ccc(C(=O)CN)cc1</smiles>

23g-23k

$$
\left(\mathrm{R}_{2}=4^{\prime}-\mathrm{Cl}[\mathrm{g}], 4^{\prime}-\mathrm{H}[\mathrm{h}], 4^{\prime}-\mathrm{F}[\mathrm{i}], 4^{\prime}-\mathrm{OCH}_{3}[\mathrm{j}], 4^{\prime}-\mathrm{CH}_{3}[\mathrm{k}]\right) .
$$

The synthesis was initiated (Figure 2) with the condensation of the acetophenone enolate 17 with a dialkyl carbonate to provide the $\beta$-ketoester $\mathbf{1 8}$ in nearly quantitative yield. Formation of the 
vinylogous amide 19 was carried out by condensation of the $\beta$-ketoester and $N, N$-dimethylformamide dimethyl acetal (DMFA) under neutral conditions. The vinylogous amide 19 was then quantitatively converted to the $\beta$-chloroenal $\mathbf{2 0}$ by reaction with thionyl chloride in THF followed by in situ hydrolysis. Condensation with an $\alpha$-amino ketone 23 (Figure 3), formed from reaction of an $\alpha$-bromoacetophenone $\mathbf{2 1}$ with sodium azide followed by triphenylphosphine reduction yielded the trisubstituted pyrroles (1-5, 7-12, Figure 4). The final condensations were carried out in the XT reactor under neutral conditions in dry DMF under dry nitrogen and at a constant temperature of $65^{\circ} \mathrm{C}$.

Figure 4: Synthesis of the 2,3,4-trisubstituted pyrroles [1-5, 7-12].<smiles>[R3]OC(=O)/C(C=O)=C(/Cl)c1ccccc1</smiles>

20a-20f<smiles>[R]c1ccc(C(=O)CN)cc1</smiles>

23g-23k

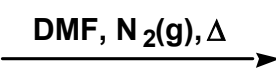<smiles>[R4]OC(=O)c1c[nH]c(C(=O)c2ccc([R2])cc2)c1-c1ccccc1</smiles>

$1-5,7-12$

Results

A series of 2,3,4-trisubstituted pyrroles was prepared (Table 1) and their lipid-lowering properties were assessed in mice and rats.

Table 1: Substitutions on the pyrroles screened for in vivo hypolipidemic activity in rodents.<smiles>[R]C(=O)c1cn([R6])cc1[R]</smiles>

\begin{tabular}{|c|c|c|c|c|}
\hline Compound & $\mathbf{R}_{\mathbf{a}^{-}}$ & $\mathbf{R}_{\mathbf{b}^{-}}$ & $\mathbf{R}_{\mathbf{c}^{-}}$ & $\mathbf{R}_{\mathbf{d}^{-}}$ \\
\hline 1 & $\mathrm{H}-$ & $4^{\prime}-\mathrm{Cl}-\mathrm{C}_{6} \mathrm{H}_{4}^{-}$ & $4^{\prime}-\mathrm{Cl}-\mathrm{C}_{6} \mathrm{H}_{4}^{-}$ & $\mathrm{H}_{3} \mathrm{CH}_{2} \mathrm{COOC}-$ \\
\hline 2 & $\mathrm{H}-$ & $\mathrm{C}_{6} \mathrm{H}_{5^{-}}$ & $4^{\prime}-\mathrm{Br}-\mathrm{C}_{6} \mathrm{H}_{4}^{-}$ & $\mathrm{H}_{3} \mathrm{CH}_{2} \mathrm{COOC}-$ \\
\hline 3 & $\mathrm{H}-$ & $\mathrm{C}_{6} \mathrm{H}_{5^{-}}$ & $3^{\prime}-\mathrm{Cl}-\mathrm{C}_{6} \mathrm{H}_{4}^{-}$ & $\mathrm{H}_{3} \mathrm{CH}_{2} \mathrm{COOC}-$ \\
\hline 4 & $\mathrm{H}-$ & 4'-F- $\mathrm{C}_{6} \mathrm{H}_{4-}$ & $4^{\prime}-\mathrm{CH}_{3}-\mathrm{C}_{6} \mathrm{H}_{4-}$ & $\mathrm{H}_{3} \mathrm{CH}_{2} \mathrm{COOC}-$ \\
\hline 5 & $\mathrm{H}-$ & $4^{\prime}-\mathrm{Cl}-\mathrm{C}_{6} \mathrm{H}_{4-}^{-}$ & $4^{\prime}-\mathrm{CH}_{3}-\mathrm{C}_{6} \mathrm{H}_{4-}^{-}$ & $\mathrm{H}_{3} \mathrm{CH}_{2} \mathrm{COOC}-$ \\
\hline 6 & $\mathrm{H}_{3} \mathrm{C}-$ & $\mathrm{CH}_{3} \mathrm{CH}_{2} \mathrm{O}-$ & $\mathrm{H}-$ & $4^{\prime}-\mathrm{Cl}-\mathrm{C}_{6} \mathrm{H}_{4}-$ \\
\hline 7 & $\mathrm{H}-$ & 4'-F- $\mathrm{C}_{6} \mathrm{H}_{4-}$ & 4'-F- $\mathrm{C}_{6} \mathrm{H}_{4-}$ & $\mathrm{H}_{3} \mathrm{CH}_{2} \mathrm{COOC}-$ \\
\hline 8 & $\mathrm{H}-$ & $4^{\prime}-\mathrm{CH}_{3} \mathrm{O}-\mathrm{C}_{6} \mathrm{H}_{4-}$ & $4^{\prime}-\mathrm{Cl}-\mathrm{C}_{6} \mathrm{H}_{4^{-}}$ & $\mathrm{H}_{3} \mathrm{CH}_{2} \mathrm{COOC}-$ \\
\hline 9 & H- & $4^{\prime}-\mathrm{Cl}-\mathrm{C}_{6} \mathrm{H}_{4}^{-}$ & $4^{\prime}-\mathrm{F}-\mathrm{C}_{6} \mathrm{H}_{4^{-}}$ & $\mathrm{H}_{3} \mathrm{CH}_{2} \mathrm{COOC}-$ \\
\hline 10 & $\mathrm{H}-$ & $4^{\prime}-\mathrm{CH}_{3}-\mathrm{C}_{6} \mathrm{H}_{4}-$ & $4^{\prime}-\mathrm{CH}_{3} \mathrm{O}-\mathrm{C}_{6} \mathrm{H}_{4}^{-}$ & $\mathrm{H}_{3} \mathrm{COOC}-$ \\
\hline 11 & $\mathrm{H}-$ & $4^{\prime}-\mathrm{CH}_{3} \mathrm{O}-\mathrm{C}_{6} \mathrm{H}_{4}-$ & $4^{\prime}-\mathrm{CH}_{3} \mathrm{O}-\mathrm{C}_{6} \mathrm{H}_{4}^{-}$ & $\mathrm{H}_{3} \mathrm{COOC}-$ \\
\hline 12 & $\mathrm{H}-$ & 4'-Cl- $\mathrm{C}_{6} \mathrm{H}_{4}^{-}$ & $4^{\prime}-\mathrm{CH}_{3} \mathrm{O}-\mathrm{C}_{6} \mathrm{H}_{4}^{-}$ & $\mathrm{H}_{3} \mathrm{COOC}-$ \\
\hline 13 & $\mathrm{H}-$ & $4^{\prime}-\mathrm{CH}_{3} \mathrm{O}-\mathrm{C}_{6} \mathrm{H}_{4}^{-}$ & $4^{\prime}-\mathrm{CH}_{3} \mathrm{O}-\mathrm{C}_{6} \mathrm{H}_{4}^{-}$ & $4^{\prime}-\mathrm{CH}_{3} \mathrm{O}-\mathrm{C}_{6} \mathrm{H}_{4-}^{-}$ \\
\hline 14 & $\mathrm{H}-$ & $\mathrm{CH}_{3} \mathrm{O}-$ & $3^{\prime}, 4^{\prime}-\left(\mathrm{CH}_{3} \mathrm{O}\right)_{2}-\mathrm{C}_{6} \mathrm{H}_{4^{-}}$ & $3^{\prime}, 4^{\prime}-\left(\mathrm{CH}_{3} \mathrm{O}\right)_{2}-\mathrm{C}_{6} \mathrm{H}_{4}$ \\
\hline 15 & $\mathrm{H}_{3} \mathrm{C}-$ & $\mathrm{CH}_{3} \mathrm{CH}_{2} \mathrm{O}-$ & $3^{\prime}, 4^{\prime}-\left(\mathrm{CH}_{3} \mathrm{O}\right)_{2}-\mathrm{C}_{6} \mathrm{H}_{4^{-}}$ & $3^{\prime}, 4^{\prime}-\left(\mathrm{CH}_{3} \mathrm{O}\right)_{2}-\mathrm{C}_{6} \mathrm{H}_{4}$ \\
\hline
\end{tabular}


Two of the pyrroles, compounds $\mathbf{1}$ and 2, were initially screened in rats at an oral dose of 2 $\mathrm{mg} / \mathrm{kg} /$ day for 14 days. Compound 1 demonstrated a $32 \%$ reduction in the total serum cholesterol levels in the rats after 14 days; however, the same compound showed an elevation in the triglycerides of $47 \%$. Compound 2 also demonstrated a 59\% elevation in the serum triglyceride levels in rats but had no effect on total cholesterol levels (Table 2).

Table 2: In Vivo Hypolipidemic Activity of the 2,3,4-trisubstituted pyrroles (1) and (2) in Sprague-Dawley Rats at $2 \mathrm{mg} / \mathrm{kg}$ /day orally for 14 days.

\begin{tabular}{|c|c|c|c|c|c|}
\hline \multirow{3}{*}{$\begin{array}{c}N=6 \\
\text { Compound }\end{array}$} & \multirow{3}{*}{$\begin{array}{l}\text { (g/rat/day) } \\
\text { Food Consumption }\end{array}$} & \multicolumn{4}{|c|}{ Percent of Control $(\boldsymbol{X} \pm \boldsymbol{S D})$} \\
\hline & & \multicolumn{2}{|c|}{ Day 7} & \multicolumn{2}{|c|}{ Day 14} \\
\hline & & Cholesterol & Triglycerides & Cholesterol & Triglycerides \\
\hline 1 & 19.13 & $98+5$ & $93+18$ & $68 \pm 16^{*}$ & $147 \pm 7 *$ \\
\hline 2 & 20.60 & $120+24$ & $85 \pm 13$ & $104 \pm 7$ & $159 \pm 8 *$ \\
\hline Atorvastatin $^{\mathrm{a}}$ & 19.03 & $110 \pm 14$ & $92 \pm 28$ & $69 \pm 6^{*}$ & $119+5 *$ \\
\hline Gemfibrozil $^{\mathrm{b}}$ & 17.47 & $122+5$ & $56 \pm 62 *$ & $116 \pm 17$ & $138+2 *$ \\
\hline Control $^{\mathrm{c}}$ & 20.06 & $100 \pm 14^{\mathrm{d}}$ & $100 \pm 7^{\mathrm{e}}$ & $100 \pm 8^{\mathrm{f}}$ & $100 \pm 6^{\mathrm{g}}$ \\
\hline \multicolumn{2}{|c|}{${ }^{\mathrm{a}}$ Dosed at $8 \mathrm{mg} / \mathrm{kg} /$ day } & \multicolumn{4}{|c|}{${ }^{\mathrm{e}} 94 \mathrm{mg} / \mathrm{dL}$ serum triglycerides } \\
\hline \multicolumn{2}{|c|}{${ }^{\mathrm{b}}$ Dosed at $90 \mathrm{mg} / \mathrm{kg} /$ day } & \multicolumn{4}{|c|}{${ }^{\mathrm{f}} 46 \mathrm{mg} / \mathrm{dL}$ total serum cholesterol } \\
\hline \multicolumn{2}{|l|}{${ }^{\mathrm{c}} 1 \% \mathrm{CMC}$} & \multicolumn{4}{|c|}{ g $56 \mathrm{mg} / \mathrm{dL}$ serum triglycerides } \\
\hline \multicolumn{2}{|c|}{ d $83 \mathrm{mg} / \mathrm{dL}$ total serum cholesterol } & \multicolumn{4}{|c|}{$* p<0.005(t$-test $)$} \\
\hline
\end{tabular}

For the rat study, tissue samples of liver, small intestine, aorta and feces were taken, homogenized in sucrose/EDTA, the lipids extracted with methanol and chloroform and analyzed for cholesterol and triglyceride content (Table 3).

Table 3: The effects of the 2,3,4-trisubstituted pyrroles (1) and (2) in Sprague-Dawley Rats at $2 \mathrm{mg} / \mathrm{kg}$ /day orally for 14 days on tissue lipid levels.

\begin{tabular}{clc}
\hline$N=6$ & \multicolumn{2}{c}{ Percent of Control $(X+S D)$} \\
\hline Compound & Cholesterol & Triglycerides \\
\hline Liver & $187 \pm 19^{*}$ & $106 \pm 20$ \\
$\mathbf{1}$ & $197 \pm 19^{*}$ & $100 \pm 40$ \\
$\mathbf{2}$ & $169 \pm 19^{*}$ & $166 \pm 35$ \\
Atorvastatin $^{\mathrm{a}}$ & $107 \pm 18$ & $96 \pm 16$ \\
Gemfibrozil $^{\mathrm{b}}$ & $100 \pm 24^{\mathrm{d}}$ & $100 \pm 35^{\mathrm{e}}$
\end{tabular}

Small intestine

$\begin{array}{lcc}\mathbf{1} & 48 \pm 13 & 127 \pm 24 \\ \mathbf{2} & 33 \pm 17 & 115 \pm 20 \\ \text { astatin }^{\mathrm{a}} & 49 \pm 15 & 55 \pm 18^{*} \\ \text { ibrozil }^{\mathrm{b}} & 75 \pm 16 & 81 \pm 28 \\ \text { ol }^{\mathrm{c}} & 100 \pm 35^{\mathrm{f}} & 100 \pm 19^{\mathrm{g}}\end{array}$




\begin{tabular}{crr}
\multicolumn{1}{c}{ Aorta } & \\
$\mathbf{1}$ & $61 \pm 12^{*}$ & $15 \pm 41^{*}$ \\
$\mathbf{2}$ & $126 \pm 18$ & $30 \pm 28^{*}$ \\
Atorvastatin $^{\mathrm{a}}$ & $105 \pm 17$ & $56 \pm 23^{*}$ \\
Gemfibrozil $^{\mathrm{b}}$ & $106 \pm 13$ & $29 \pm 22^{*}$ \\
Control $^{\mathrm{c}}$ & $100 \pm 15^{\mathrm{h}}$ & $100 \pm 14^{\mathrm{i}}$
\end{tabular}

Feces

1

$123 \pm 18$

$84 \pm 20$

2

$94+10$

$92 \pm 16$

Atorvastatin $^{\mathrm{a}}$

$178 \pm 54$

$85 \pm 16$

Gemfibrozil $^{\mathrm{b}}$

$106+13$

$98+23$

Control $^{\mathrm{c}}$

$100 \pm 22^{\mathrm{j}}$

$100+24^{k}$

${ }^{a}$ Dosed at $8 \mathrm{mg} / \mathrm{kg} / \mathrm{day}$

${ }^{\mathrm{b}}$ Dosed at $90 \mathrm{mg} / \mathrm{kg} /$ day

c $1 \% \mathrm{CMC}$

d $3.17 \mathrm{mg} / \mathrm{g}$ (wet tissue)

e $3.31 \mathrm{mg} / \mathrm{dL}$ (wt)

f $12.68 \mathrm{mg} / \mathrm{dL}$ (wt) g $12.78 \mathrm{mg} / \mathrm{g}(\mathrm{wt})$

h $2.97 \mathrm{mg} / \mathrm{dL}$ (wt)

I $13.85 \mathrm{mg} / \mathrm{dL}$ (wt)

j $7.92 \mathrm{mg} / \mathrm{dL}$ (wt)

${ }^{\mathrm{k}} 9.44 \mathrm{mg} / \mathrm{dL}$ (wt)

$* p<0.005$ ( $t$-test)

Both compounds 1 and $\mathbf{2}$ demonstrated an elevation in the cholesterol content of the liver by 87 and $97 \%$, respectively, without any effects on the triglyceride content. Both compounds 1 and 2 also reduced the cholesterol content of the small intestine by 52 and $67 \%$, respectively and showed a slight elevation of 27 and 15\%, respectively of the triglyceride content. Compounds $\mathbf{1}$ and $\mathbf{2}$ demonstrated a marked reduction on the triglyceride content of the aorta with compound 1 also demonstrating a 39\% reduction in the cholesterol content. Neither compound demonstrated any significant effects on the lipid content of the feces although compound 1 elevated fecal cholesterol levels $23 \%$ which was not significantly different from the control.

An expanded series of the pyrroles was subsequently tested in mice. The new agents demonstrated potent hypolipidemic effects in mice after 14 days of I.P. dosing at $8 \mathrm{mg} / \mathrm{kg} /$ day for compounds 3-12 and $4 \mathrm{mg} / \mathrm{kg} /$ day for compounds 13-15 (Table 4). Compounds 3, 7, 13 and 14 lowered both serum cholesterol and triglyceride levels in mice by at least $24 \%$ and $33 \%$, respectively. The most effective agent in the series was compound 14, which demonstrated cholesterol and triglyceride-lowering effects at both 7 and 14 day sampling points achieving a 34\% reduction in total serum cholesterol and $38 \%$ reduction in serum triglyceride concentrations at $4 \mathrm{mg} / \mathrm{kg} / \mathrm{day}$. Compound 4 also demonstrated a cholesterol-lowering effect of $34 \%$, but its triglyceride-lowering effects were not sustained after 14 days. Compounds 6 and 15 demonstrated a slight cholesterol reduction of 18 and 11\%, respectively. Compounds 8, 9, 10 and 12 demonstrated a reduction in serum triglyceride levels of 33 to $48 \%$ without any effects on the cholesterol levels. An analysis of the serum lipoprotein cholesterol levels, LDLcholesterol and HDL-cholesterol, showed a remarkable reduction in LDL-cholesterol of 61 to $35 \%$ in the mice dosed with compounds 7, 8, 9, 11, 12, 13 and 15 (Table 5). The HDL-cholesterol levels were concomitantly reduced in the mice by compounds 7, 8, 10 and $\mathbf{1 3}$ demonstrating a 54 to $18 \%$ 
reduction. However, compounds 9, 12 and $\mathbf{1 5}$ produced an elevation of the mice HDL-cholesterol by 183, 103 and 150\%, respectively. Compound 14 also demonstrated a $48 \%$ increase in the mouse serum HDL-cholesterol.

Table 4: In Vivo Hypolipidemic Activity of the substituted pyrroles (3-15) in CF-1 male mice at $8 \mathrm{mg} / \mathrm{kg} /$ day, IP for 14 days.

\begin{tabular}{|c|c|c|c|c|}
\hline \multirow{2}{*}{$N=6$} & \multicolumn{4}{|c|}{ Percent of Control $(X+S D)$} \\
\hline & \multicolumn{2}{|c|}{ Day 7} & \multicolumn{2}{|c|}{ Day 14} \\
\hline Compound & Cholesterol & Triglycerides & Cholesterol & Triglycerides \\
\hline 3 & $68 \pm 11 *$ & $28 \pm 29 *$ & $72 \pm 8^{*}$ & $59 \pm 37$ \\
\hline 4 & $69 \pm 9 *$ & $54+5 *$ & $66 \pm 11 *$ & $113+43$ \\
\hline 5 & $73 \pm 8^{*}$ & $99+8$ & $87 \pm 8$ & $184+28$ \\
\hline 6 & $97 \pm 7$ & $62 \pm 7 *$ & $82 \pm 9 *$ & $109+20$ \\
\hline 7 & $67 \pm 15^{*}$ & $56 \pm 24 *$ & $76 \pm 14$ & $61 \pm 30 *$ \\
\hline 8 & $79 \pm 14 *$ & $91 \pm 31$ & $91 \pm 13$ & $53 \pm 23 *$ \\
\hline 9 & $95 \pm 8$ & $58 \pm 14 *$ & $91 \pm 18$ & $52 \pm 23 *$ \\
\hline 10 & $93 \pm 10$ & $70 \pm 19$ & $98 \pm 17$ & $60 \pm 21 *$ \\
\hline 11 & $89+9$ & $76 \pm 26$ & $90 \pm 17$ & $77+30$ \\
\hline 12 & $102 \pm 12 *$ & $67 \pm 11 *$ & $103 \pm 12$ & $67 \pm 31$ \\
\hline $13^{\mathrm{a}}$ & $80 \pm 13 *$ & $49 \pm 17 *$ & $76 \pm 8^{*}$ & $65 \pm 28 *$ \\
\hline $14^{\mathrm{a}}$ & $62 \pm 19 *$ & $55+20 *$ & $66 \pm 14 *$ & $62+23 *$ \\
\hline $15^{\mathrm{a}}$ & $75+9 *$ & $83 \pm 14$ & $89 \pm 3 *$ & $76 \pm 24$ \\
\hline Atorvastatin $^{\mathrm{b}}$ & $77 \pm 6^{*}$ & $66+11 *$ & $81 \pm 17$ & $84+33$ \\
\hline Gemfibrozil $^{\mathrm{c}}$ & $62 \pm 11 *$ & $43 \pm 21 *$ & $57 \pm 13^{*}$ & $82 \pm 15$ \\
\hline Niacin $^{\mathrm{d}}$ & $97 \pm 18$ & $70 \pm 8$ & $93 \pm 24$ & $102+21$ \\
\hline Control $^{\mathrm{e}}$ & $100 \pm 14^{\mathrm{f}}$ & $100 \pm 7^{\mathrm{g}}$ & $100 \pm 8^{\mathrm{h}}$ & $100 \pm 6^{\mathrm{i}}$ \\
\hline${ }^{\mathrm{a}}$ Dosed at $4 \mathrm{~m}$ & & ${ }^{\mathrm{f}} 188 \mathrm{mg} / \mathrm{dL}$ tc & holesterol & \\
\hline${ }^{\mathrm{b}}$ Dosed at $8 \mathrm{~m}$ & & g $231 \mathrm{mg} / \mathrm{dL} \mathrm{s}$ & erides & \\
\hline${ }^{\mathrm{c}}$ Dosed at 90 & & h $164 \mathrm{mg} / \mathrm{dL} \mathrm{t}$ & holesterol & \\
\hline${ }^{\mathrm{d}}$ Dosed at 12. & & ${ }^{\mathrm{i}} 179 \mathrm{mg} / \mathrm{dL} \mathrm{s}$ & erides & \\
\hline${ }^{\mathrm{e}} 1 \% \mathrm{CMC}, \mathrm{PC}$ & & $* p<0.005$ & & \\
\hline
\end{tabular}

\section{Discussion}

Many of the 2,3,4-trisubstituted pyrroles in this series demonstrated potent lipid-lowering effects in mice at 4-8 mg/kg/day I.P. or rats at $2 \mathrm{mg} / \mathrm{kg}$ /day orally. While selected compounds 3, 7, 13 and 14 showed a reduction in both the total serum cholesterol and triglyceride concentrations, the most profound effects were with the reduction in serum triglyceride levels by compounds $3,7,8,9,10,12$, 13 and 14 (Table 4). The most effective lipid-lowering compound was compound $\mathbf{1 4}$ demonstrating an early and sustained reduction of both total serum cholesterol and triglycerides in addition to showing an elevation in the HDL-cholesterol, the lipoprotein fraction that offers protection against atherosclerosis development. Compound 14, which also contains the 3',4'-dimethoxyphenyl 
substituents has been previously synthesized [36] and employed as the precursor to the marine natural product Ningalin B (Figure 5). The related $N$-methyl Ningalin B precursor, 15, was much less active indicating that a free N-H functionality may be necessary for activity. In contrast to the active HMGCoA reductase inhibitors, such as atorvastatin and fluvastatin, which are pentasubstituted pyrroles, most of the active pyrroles contain a free N-H functionality. Likewise, since none of the compounds studied contained a 3,5-dihydroxyheptanoate group, it is postulated that these compounds do not inhibit the activity of HMG CoA reductase. A common feature between the active compounds presented here and the statins is at least one 4'-halo- (-Cl or -F) or 4'-methoxyphenyl group. In fact, the next best agent in this study was compound 7, which has 4'-fluorophenyl groups in both the 3 and 4 positions of the pyrrole ring.

Figure 5: Structure of the marine natural product Ningalin B.

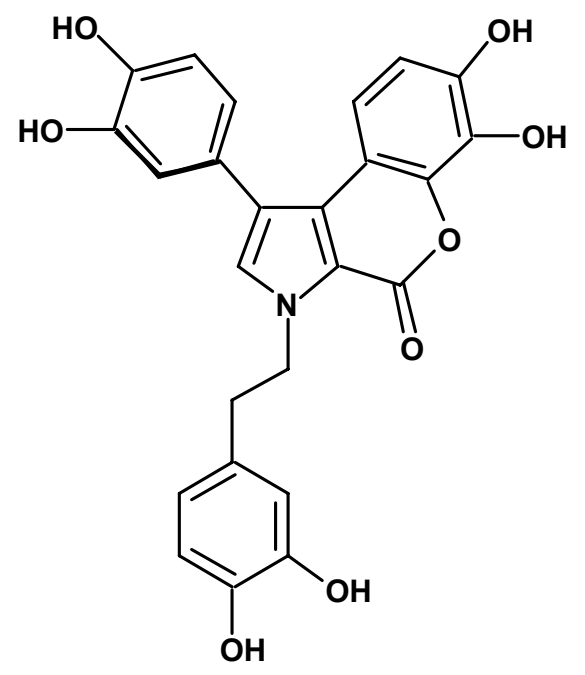

Table 5: In Vivo Hypolipidemic Activity of the substituted pyrroles (3-15) in CF-1 male mice at $8 \mathrm{mg} / \mathrm{kg} /$ day, IP for 14 days.

\begin{tabular}{ccc}
\hline$N=6$ & \multicolumn{2}{c}{ Percent of Control $(X \pm S D)$} \\
\hline Compound & LDL-Cholesterol & HDL-Cholesterol \\
\hline $\mathbf{3}$ & - & $102 \pm 20$ \\
$\mathbf{4}$ & - & $112 \pm 24$ \\
$\mathbf{5}$ & - & $109 \pm 21$ \\
$\mathbf{6}$ & - & $130 \pm 12$ \\
$\mathbf{7}$ & $47 \pm 21^{*}$ & $63 \pm 53$ \\
$\mathbf{8}$ & $65 \pm 40^{*}$ & $56 \pm 38$ \\
$\mathbf{9}$ & $53 \pm 31$ & $283 \pm 10^{*}$ \\
$\mathbf{1 0}$ & $106 \pm 5$ & $46 \pm 31^{*}$ \\
$\mathbf{1 1}$ & $47 \pm 15^{*}$ & $96 \pm 63$ \\
$\mathbf{1 2}$ & $47 \pm 25^{*}$ & $203 \pm 21$ \\
$\mathbf{1 3}$ & $39 \pm 34^{*}$ & $82 \pm 31$ \\
$\mathbf{1 4}$ & $114 \pm 21$ & $148 \pm 4$
\end{tabular}




\begin{tabular}{lcc}
\multicolumn{1}{c}{$\mathbf{1 5}^{\mathrm{a}}$} & $156 \pm 17$ & $250 \pm 11$ \\
Atorvastatin $^{\mathrm{b}}$ & - & $178 \pm 34$ \\
Gemfibrozil $^{\mathrm{c}}$ & - & $192 \pm 8^{*}$ \\
Niacin $^{\mathrm{d}}$ & - & $152 \pm 19$ \\
Control $^{\mathrm{e}}$ & $100 \pm 15^{\mathrm{f}}$ & $100 \pm 14^{\mathrm{g}}$ \\
${ }^{\mathrm{a}}{ }^{\mathrm{D}}$ Dosed at $4 \mathrm{mg} / \mathrm{kg} /$ day, IP & \multicolumn{2}{c}{$1 \% \mathrm{CMC}$, PO } \\
${ }^{\mathrm{b}}$ Dosed at $8 \mathrm{mg} / \mathrm{kg} /$ day, IP & & ${ }^{\mathrm{f}} 86 \mathrm{mg} / \mathrm{dL}$ LDL-Cholesterol \\
${ }^{\mathrm{c}}$ Dosed at $90 \mathrm{mg} / \mathrm{kg} /$ day, IP & & ${ }^{\mathrm{g}} 63 \mathrm{mg} / \mathrm{dL}$ HDL-Cholesterol \\
${ }^{\mathrm{d}}$ Dosed at $12.5 \mathrm{mg} / \mathrm{kg} /$ day, IP & & $* p<0.005(t$-test $)$
\end{tabular}

But while compound 7 showed a reduction in LDL-cholesterol levels, it also showed a reduction in HDL-cholesterol levels. For compounds, 9 and 12 which showed the desired lipoprotein modulations (e.g., a reduction in LDL-cholesterol with a concomitant elevation in the HDL-cholesterol) only the serum triglyceride levels, were significantly reduced. Compounds $\mathbf{9}$ and $\mathbf{1 2}$ also fit the pattern of 4'halo- or 4'-methoxyphenyl groups in positions 3 and 4 of the pyrrole ring. In the orally dosed rats, compound 1, containing a 4'-chlorophenyl group in the 3 and 4 positions, demonstrated cholesterollowering effects in the serum at $2 \mathrm{mg} / \mathrm{kg} / \mathrm{day}$. However, compound $\mathbf{1}$ showed an elevation in the serum triglyceride levels in contrast to the effects observed with structurally similar compounds in the mouse study. Fecal elimination of cholesterol or triglycerides did not appear to be involved in the lipidlowering effect of compound $\mathbf{1}$. The reduction of the cholesterol and triglyceride content of the aorta by compound $\mathbf{1}$ is a favorable response in relation to the development of atherosclerosis and cardiovascular disease. Like atorvastatin, compounds $\mathbf{1}$ and $\mathbf{2}$ also demonstrated an increase in the cholesterol content of the liver indicating that some effect on cholesterol metabolism is occurring due to the administration of compounds $\mathbf{1}$ and $\mathbf{2}$. The reduction in the cholesterol content of the small intestine by compounds $\mathbf{1}$ and $\mathbf{2}$ also suggests that an effect on cholesterol metabolism had occurred since the fecal elimination of cholesterol was not observed. Fecal elimination was not evident on day 14 , but for compound 1 , a $23 \%$ increase was present which may reflect a trend in fecal elimination.

\section{Conclusions}

A series of 2,3,4-trisubstituted pyrroles was synthesized and selected agents demonstrated potent hypolipidemic activity in mice and rats at $2-8 \mathrm{mg} / \mathrm{kg} /$ day lowering the total serum cholesterol and triglycerides levels. The pyrroles overall demonstrated more of an effect in reducing triglycerides than reducing cholesterol. Selected agents also showed a reduction in LDL-cholesterol along with an elevation in HDL-cholesterol. The magnitude of the total serum cholesterol reduction, HDLcholesterol elevation and the modulations of the cholesterol content of the liver and small intestine demonstrate similarities between compound $\mathbf{1}$ and atorvastatin, the standard HMG-CoA reductase inhibitor. However, many of the pyrroles were more effective as hypotriglyceridemic agents than atorvastatin. These observations and the fact that these pyrroles are not fully substituted nor contain the 3,5-dihydroxyheptanoate side chain, lead to the conclusion that the trisubstituted pyrrole do not exert their lipid-lowering effects via the inhibition of HMG-CoA reductase activity. 
The most active pyrrole derivatives contain some of the structural similarities to atorvastatin and fluvastatin including a 4'-halophenyl substituents and a carbonyl-containing substituent, but differ in that they do not contain the dihydroxyheptanoate group. The statins also show interesting metabolic effects outside that of the inhibition of HMG-CoA reductase activity. Therefore, these 2,3,4trisubstituted pyrroles may represent a new class of lipid-lowering agents.

\section{Acknowledgements}

The authors would like to thank Mettler-Toledo AutoChem for equipment and financial support to BSB, American Cyanamid for its Grant-in-Aid to BSB, Project SEED of the American Chemical Society and the NSF NMR-Collaborative Training Partnership Grant (DUE-9952369) for the $300 \mathrm{MHz}$ Bruker Avance FT-NMR at Rider University. We would like to express our gratitude to Dr. Jennifer Smith of Berger Instruments, Inc. for the SFC/MS analyses.

\section{Experimental}

\section{General:}

All chemicals and reagents were obtained from Sigma-Aldrich Chemical Company (Milwaukee, WI) and used as received. Solvents were stored over 4A molecular sieves and used as received, except for dry solvents, which were dried and distilled using standard procedures [34]. TLC was performed using silica gel 60F 254 plates (silica gel on plastic, Aldrich Chemical Company). Melting points were obtained on a Thomas-Hoover Uni-melt apparatus (capillary method), and were uncorrected. All boiling points were obtained under reduced pressure and noted at the temperature of first moisture deposit in receiving flask. IR spectra were obtained on a Perkin-Elmer 1600 FTIR spectrometer on sodium chloride plates or in a potassium chloride liquid cell in $\mathrm{CHCl}_{3}$ or $\mathrm{CDCl}_{3}$. NMR spectra were obtained on a $300 \mathrm{MHz}$ Bruker Avance FT-NMR spectrometer. Unless stated otherwise $\mathrm{CDCl}_{3}$ and tetramethylsilane were used as solvent and external standard $(\delta=0 \mathrm{ppm})$, respectively, for ${ }^{1} \mathrm{H}$ and ${ }^{13} \mathrm{C}$ spectra. Elemental analyses were performed by Quantitative Technologies, Inc. (Whitehouse, NJ). SFC/MS was on a Berger SFC/MS apparatus fitted with a Waters ZQ mass detector using a pyridine gradient (Berger Instruments, Inc., Newark, DE). HRMS-CI was performed by the University of Minnesota Mass Spectrometry Service Laboratory (Minneapolis, MN).

\section{Chemistry}

General Preparation of the $\beta$-ketoesters 18a-f: Four eq of $\mathrm{NaH}$, as a $60 \%$ mineral oil dispersion, were placed in a round bottom flask under $\mathrm{N}_{2}$ and washed with hexanes $(3 \times 50 \mathrm{~mL})$, then toluene $(150 \mathrm{~mL})$ and 5 eq of the dialkyl carbonate were added. To the resulting suspension, 1 eq of acetophenone was slowly added over $1 \mathrm{hr}$ with stirring at $\mathrm{rt}$. The solution was then stirred at reflux overnight. The resulting mixture was cooled to $\mathrm{rt}$. and glacial acetic acid $(35 \mathrm{~mL})$ was added and this was followed by 
dilution with a solution of of conc. $\mathrm{HCl}(20 \mathrm{~mL})$ in ice water $(150 \mathrm{~mL})$. The aqueous solution was extracted with ethyl acetate $(3 \mathrm{X} 75 \mathrm{~mL})$. The organic layers were neutralized by extraction with sat. $\mathrm{NaHCO}_{3}$ and dried over sodium sulfate. The volatiles were then removed under reduced pressure. The crude oil was purified by Kugelrohr distillation.

Ethyl 3-(4'-Chlorophenyl)-3-oxopropionate (18a)[1]. Obtained from 4'-chloroacetophenone and diethyl carbonate as a clear oil $(54 \%)$; bp $=121-123^{\circ} \mathrm{C}$ at $0.5 \mathrm{mmHg}{ }^{1} \mathrm{H}-\mathrm{NMR} \delta=7.81(2 \mathrm{H}, \mathrm{d}, J=8.2 \mathrm{~Hz})$, $7.37(2 \mathrm{H}, \mathrm{d}, J=8.2 \mathrm{~Hz}), 4.13(2 \mathrm{H}, \mathrm{q}, J=7.2 \mathrm{~Hz}), 3.88(2 \mathrm{H}, \mathrm{s}), 1.18(3 \mathrm{H}, \mathrm{t}, J=7.2 \mathrm{~Hz}) \mathrm{ppm} ;{ }^{13} \mathrm{C}-$ NMR $\delta=192,168,141,132,130.3,129.5,62,46,15 \mathrm{ppm}\left(\mathrm{C}_{11} \mathrm{H}_{11} \mathrm{ClO}_{3}\right)$.

Ethyl 3-(4'-Bromophenyl)-3-oxopropionate (18b)[1]. Obtained from 4'-bromoacetophenone and diethyl carbonate as a clear oil $(82 \%)$; bp $=129-131^{\circ} \mathrm{C}$ at $0.6 \mathrm{mmHg}{ }^{1} \mathrm{H}-\mathrm{NMR} \delta=7.76(2 \mathrm{H}, \mathrm{d}, J=8.5 \mathrm{~Hz})$, $7.76(2 \mathrm{H}, \mathrm{d}, J=8.5 \mathrm{~Hz}), 4.08(2 \mathrm{H}, \mathrm{q}, J=7.2 \mathrm{~Hz}), 3.82(2 \mathrm{H}, \mathrm{s}), 1.13(3 \mathrm{H}, \mathrm{t}, J=7.2 \mathrm{~Hz}) \mathrm{ppm} ;{ }^{13} \mathrm{C}-\mathrm{NMR}$ $\delta=191,167,140,135,131,129,62,46,14 \mathrm{ppm}\left(\mathrm{C}_{11} \mathrm{H}_{11} \mathrm{BrO}_{3}\right)$.

Ethyl 3-(3'-Chlorophenyl)-3-oxopropionate (18c)[1]. Obtained from 3'-chloroacetophenone and diethyl carbonate as a clear oil $(47 \%)$; bp $=114-116^{\circ} \mathrm{C}$ at $0.5 \mathrm{mmHg}{ }^{1} \mathrm{H}-\mathrm{NMR} \delta=7.83(1 \mathrm{H}, \mathrm{s}), 7.02-7.75(3 \mathrm{H}$, m), $4.11(2 \mathrm{H}, \mathrm{q}, J=7.2 \mathrm{~Hz}), 3.85(2 \mathrm{H}, \mathrm{s}), 1.22(3 \mathrm{H}, \mathrm{t}, J=7.2 \mathrm{~Hz}) \mathrm{ppm} ;{ }^{13} \mathrm{C}-\mathrm{NMR} \delta=192,167,138$, $136,134,131,129,127,62,46,14 \mathrm{ppm}\left(\mathrm{C}_{11} \mathrm{H}_{11} \mathrm{ClO}_{3}\right)$.

Ethyl 3-(4'-Methylphenyl)-3-oxopropionate (18d) [1]. Obtained from 4'-methylacetophenone and diethyl carbonate as a clear oil $(58 \%) ; \mathrm{bp}=139^{\circ} \mathrm{C}$ at $0.2 \mathrm{mmHg} ;{ }^{1} \mathrm{H}-\mathrm{NMR} \delta=7.81(2 \mathrm{H}, \mathrm{d}, J=8.1 \mathrm{~Hz})$, $7.23(2 \mathrm{H}, \mathrm{d}, J=8.1 \mathrm{~Hz}), 4.18(2 \mathrm{H}, \mathrm{q}, J=7.2 \mathrm{~Hz}), 3.91(2 \mathrm{H}, \mathrm{s}), 2.38(3 \mathrm{H}, \mathrm{s}), 1.23(3 \mathrm{H}, \mathrm{t}, J=7.2 \mathrm{~Hz})$ ppm; ${ }^{13} \mathrm{C}-\mathrm{NMR} \delta=192,167,144,134,130,129,62,46,22,14 \mathrm{ppm}\left(\mathrm{C}_{12} \mathrm{H}_{14} \mathrm{O}_{3}\right)$.

Ethyl 3-(4'-Fluorophenyl)-3-oxopropionate (18e). Obtained from 4'-fluoroacetophenone and diethyl carbonate as a clear oil $(100 \%) ;{ }^{1} \mathrm{H}-\mathrm{NMR} \delta=7.98\left(2 \mathrm{H}, \mathrm{d}\right.$ of d, $\left.J_{H, F}=5.3 \mathrm{~Hz}, J_{H, H}=8.8 \mathrm{~Hz}\right), 7.14(2 \mathrm{H}$, $\mathrm{t}, J=8.8 \mathrm{~Hz}), 4.21(2 \mathrm{H}, \mathrm{q}, J=7.2 \mathrm{~Hz}), 3.97(2 \mathrm{H}, \mathrm{s}), 1.25(3 \mathrm{H}, \mathrm{t}, J=7.2 \mathrm{~Hz}) ;{ }^{13} \mathrm{C}-\mathrm{NMR} \delta=191.07$, $191.03,\left[167.38,164.44\left(\mathrm{~d}, J_{C, F}=256 \mathrm{~Hz}\right)\right], 167.39,131.39,115.86,61.55,45.96,14.09$ ppm $\left(\mathrm{C}_{11} \mathrm{H}_{11} \mathrm{FO}_{3}\right)$.

Methyl 3-(4'-Methoxyphenyl)-3-oxopropionate (18f). Obtained from 4'-methoxyacetophenone and dimethyl carbonate as a clear oil $(77 \%)$; bp $=154-156^{\circ} \mathrm{C}$ at $1.2 \mathrm{mmHg} ;{ }^{1} \mathrm{H}-\mathrm{NMR} \delta=7.87(2 \mathrm{H}, \mathrm{d}, J=9$ $\mathrm{Hz}), 7.43(2 \mathrm{H}, \mathrm{d}, J=9 \mathrm{~Hz}), 3.98(3 \mathrm{H}, \mathrm{s}), 3.79(2 \mathrm{H}, \mathrm{s}), 3.73(3 \mathrm{H}, \mathrm{s}) ;{ }^{13} \mathrm{C}-\mathrm{NMR} \delta=191.20,168.48$, $164.29,131.14,129.31,114.24,55.76,52.51,45.63 \mathrm{ppm}\left(\mathrm{C}_{11} \mathrm{H}_{12} \mathrm{O}_{4}\right)$.

General Preparation of the Vinylogous Amides 19: To 1 eq of the $\beta$-ketoester in dry DMF (100mL) was added 3.5 eq of N,N-dimethylformamide dimethylacetal (DMFA). The solution was refluxed overnight then cooled to room temperature and the DMF was removed via Kugelrohr distillation. The yields were quantitative and the dark oils were used without further purification. 
Ethyl 1-(4'-Chlorophenyl)-3-(dimethylamino)prop-2-enone-2-carboxylate (19a) [1]. Obtained from ethyl 3-(4'-chlorophenyl)-3-oxopropionate (18a) as a dark brown oil (93\%); ${ }^{1} \mathrm{H}-\mathrm{NMR}$ of $Z$ isomer $\delta=$ 7.53-7.76 (3H, m), $7.29(2 \mathrm{H}, \mathrm{d}, J=8.7 \mathrm{~Hz}), 3.90(2 \mathrm{H}, \mathrm{q}, J=7.2 \mathrm{~Hz}), 2.92(6 \mathrm{H}, \mathrm{br} \mathrm{s}), 0.88(3 \mathrm{H}, \mathrm{t}, J=$ $7.2 \mathrm{~Hz}) \mathrm{ppm} ;{ }^{13} \mathrm{C}-\mathrm{NMR}$ of $Z$ isomer $\delta=192.91,168.79,156.61,130.61,130.46,129.92,128.58$, 128.17, 60.19, $14.34 \mathrm{ppm}\left(\mathrm{C}_{14} \mathrm{H}_{16} \mathrm{ClNO}_{3}\right)$.

Ethyl 1-(4'-Bromophenyl)-3-(dimethylamino)prop-2-enone-2-carboxylate (19b)[1]. Obtained from ethyl 3-(4'-bromophenyl)-3-oxopropionate (18b) as a dark brown oil $(66 \%)$; ${ }^{1} \mathrm{H}-\mathrm{NMR}$ of $Z$ isomer $\delta=$ $7.66(1 \mathrm{H}, \mathrm{s}), 7.56(2 \mathrm{H}, \mathrm{d}, J=8.4 \mathrm{~Hz}), 7.45(2 \mathrm{H}, \mathrm{d}, J=8.4 \mathrm{~Hz}), 3.90(2 \mathrm{H}, \mathrm{q}, J=7.2 \mathrm{~Hz}), 2.88(6 \mathrm{H}$, br s), $0.87(3 \mathrm{H}, \mathrm{t}, J=7.2 \mathrm{~Hz}) \mathrm{ppm} ;{ }^{13} \mathrm{C}-\mathrm{NMR}$ of $Z$ isomer $\delta=191.65,167.42,161.49,155.31,131.10$, $130.68,130.14,129.79,128.81,58.80,12.92 \mathrm{ppm}\left(\mathrm{C}_{14} \mathrm{H}_{16} \mathrm{BrNO}_{3}\right)$.

Ethyl 1-(3'-Chlorophenyl)-3-(dimethylamino)prop-2-enone-2-carboxylate (19c)[1]. Obtained from ethyl 3-(3'-chlorophenyl)-3-oxopropionate (18c) as a dark brown oil (68\%); ${ }^{1} \mathrm{H}-\mathrm{NMR}$ of $Z$ isomer $\delta=$ $7.92(1 \mathrm{H}, \mathrm{s}), 7.30-7.82(4 \mathrm{H}, \mathrm{m}), 4.21(2 \mathrm{H}, \mathrm{q}, J=7.2 \mathrm{~Hz}), 3.03(6 \mathrm{H}, \mathrm{br} \mathrm{s}), 1.25(3 \mathrm{H}, \mathrm{t}, J=7.2 \mathrm{~Hz}) \mathrm{ppm}$; ${ }^{13} \mathrm{C}-\mathrm{NMR}$ of $Z$ isomer $\delta=191.70,167.48,163.37,157.09,130.49,129.72,129.64,129.61,128.95$, 127.76, 127.02, 62.04, $14.45 \mathrm{ppm}\left(\mathrm{C}_{14} \mathrm{H}_{16} \mathrm{ClNO}_{3}\right)$.

Ethyl 1-(4'-Methylphenyl)-3-(dimethylamino)prop-2-enone-2-carboxylate (19d)[1]. Obtained from ethyl 3-(4'-methylphenyl)-3-oxopropionate (18d) as a dark brown oil (85\%); bp=138-143 ${ }^{\circ} \mathrm{C}$ at 3 mmHg; ${ }^{1} \mathrm{H}-\mathrm{NMR}$ of $Z$ isomer $\delta=7.93,(1 \mathrm{H}, \mathrm{s}), 7.58(2 \mathrm{H}, \mathrm{d}, J=8.1 \mathrm{~Hz}), 7.10(2 \mathrm{H}, \mathrm{d}, J=8.1 \mathrm{~Hz}), 3.90$ $(2 \mathrm{H}, \mathrm{q}, J=7.1 \mathrm{~Hz}), 2.86(6 \mathrm{H}, \mathrm{br} \mathrm{s}), 2.30(3 \mathrm{H}, \mathrm{s}), 0.87(3 \mathrm{H}, \mathrm{t}, J=7.1 \mathrm{~Hz}) \mathrm{ppm} ;{ }^{13} \mathrm{C}-\mathrm{NMR}$ of $Z$ isomer $\delta$ $=194,169,155,142,139,129.3,129.0,126,60,44,22,14 \mathrm{ppm}\left(\mathrm{C}_{15} \mathrm{H}_{19} \mathrm{NO}_{3}\right)$.

Ethyl 1-(4'-Fluorophenyl)-3-(dimethylamino)prop-2-enone-2-carboxylate (19e). Obtained from ethyl 3-(4'-fluorophenyl)-3-oxopropionate (18e) as a dark brown oil (74\%); ${ }^{1} \mathrm{H}-\mathrm{NMR} \delta=7.79(2 \mathrm{H}$, br. s) $7.70(1 \mathrm{H}, \mathrm{s}) 7.05(2 \mathrm{H}, \mathrm{t}, J=9 \mathrm{~Hz}), 3.96(2 \mathrm{H}, \mathrm{q}, J=7 \mathrm{~Hz}), 2.96(6 \mathrm{H}$, br. s), $.925(3 \mathrm{H}, \mathrm{t}, J=7 \mathrm{~Hz})$ $\left(\mathrm{C}_{14} \mathrm{H}_{16} \mathrm{FNO}_{3}\right)$.

Methyl 1-(4'-Methoxyphenyl)-3-(dimethylamino)prop-2-enone-2-carboxylate (19f). Obtained from methyl 3-(4'-methoxyphenyl)-3-oxopropionate (18f) as a dark brown oil (81\%); ${ }^{1} \mathrm{H}-\mathrm{NMR}$ of $Z$ isomer $\delta=7.75(2 \mathrm{H}$, br. s), $7.60(1 \mathrm{H}$, br. s), $6.82(2 \mathrm{H}, \mathrm{d}, J=9 \mathrm{~Hz}), 3.78(3 \mathrm{H}, \mathrm{s}), 3.46(3 \mathrm{H}, \mathrm{s}), 2.86(6 \mathrm{H}$, br. s) $\left(\mathrm{C}_{14} \mathrm{H}_{17} \mathrm{NO}_{4}\right)$.

General Preparation of the $\beta$-Chloroenals 20: To the vinylogous amide in dry THF (300 $\mathrm{mL})$ was slowly added 3.5 eq of thionyl chloride. The reaction was brought to $50^{\circ} \mathrm{C}$ for 4 hours. $\mathrm{dH}_{2} \mathrm{O}(200 \mathrm{~mL})$ was very slowly added and the reaction and heated to $50^{\circ} \mathrm{C}$ for $2-3 \mathrm{hrs}$. The solution was cooled to $\mathrm{rt}$. and extracted with ethyl acetate $(3 \times 100 \mathrm{~mL})$. The organic layers were dried over sodium sulfate and the volatiles were removed under reduced pressure. The reaction afforded a mixture of $E$ and $Z$ isomers. NMR data was recorded for the major isomer. 
Ethyl 3-(4'-Chlorophenyl)-3-chloropropenal-2-carboxylate (20a) [1]. Obtained from ethyl 1-(4'chlorophenyl)-3-(dimethylamino)prop-2-enone-2-carboxylate (19a) as a pale yellow oil (51\%); bp = $132-134^{\circ} \mathrm{C}$ at $0.35 \mathrm{mmHg} ;{ }^{1} \mathrm{H}-\mathrm{NMR}$ of $Z$ isomer $\delta=9.28(1 \mathrm{H}, \mathrm{s}), 7.42(2 \mathrm{H}, \mathrm{d}, J=8.8 \mathrm{~Hz}), 7.32(2 \mathrm{H}, \mathrm{d}$, $J=8.8 \mathrm{~Hz}), 4.31(2 \mathrm{H}, \mathrm{q}, J=7.2 \mathrm{~Hz}), 1.29(3 \mathrm{H}, \mathrm{t}, J=7.2 \mathrm{~Hz}) \mathrm{ppm} ;{ }^{13} \mathrm{C}-\mathrm{NMR}$ of $Z$ isomer $\delta=186.07$, $164.00,153.88,138.73,136.34,132.54,131.54,131.53,129.61,62.77,14.45 \mathrm{ppm}\left(\mathrm{C}_{12} \mathrm{H}_{10} \mathrm{Cl}_{2} \mathrm{O}_{3}\right)$.

Ethyl 3-(4'-Bromophenyl)-3-chloropropenal-2-carboxylate (20b) [1]. Obtained from ethyl 1-(4'bromophenyl)-3-(dimethylamino)prop-2-enone-2-carboxylate (19b) as a pale yellow oil (22\%); bp = $138-140^{\circ} \mathrm{C}$ at $0.35 \mathrm{mmHg} ;{ }^{1} \mathrm{H}-\mathrm{NMR}$ of $Z$ isomer $\delta=9.28(1 \mathrm{H}, \mathrm{s}), 7.54(2 \mathrm{H}, \mathrm{d}, J=8.7 \mathrm{~Hz}), 7.30(2 \mathrm{H}, \mathrm{d}$, $J=8.7 \mathrm{~Hz}), 4.31(2 \mathrm{H}, \mathrm{q}, J=7.2 \mathrm{~Hz}), 1.28(3 \mathrm{H}, \mathrm{t}, J=7.2 \mathrm{~Hz}) \mathrm{ppm} ;{ }^{13} \mathrm{C}-\mathrm{NMR}$ of $Z$ isomer $\delta=187.21$, $165.14,155.09,137.49,134.18,133.76,132.83,128.26,63.92,15.63 \mathrm{ppm}\left(\mathrm{C}_{12} \mathrm{H}_{10} \mathrm{BrClO}_{3}\right)$.

Ethyl 3-(3'-Chlorophenyl)-3-chloropropenal-2-carboxylate (20c) [1]. Obtained from ethyl 1-(3'-chlorophenyl)-3-(dimethylamino)prop-2-enone-2-carboxylate (19c) as a pale yellow oil $(34 \%)$; bp $=134^{\circ} \mathrm{C}$ at $0.3 \mathrm{mmHg} ;{ }^{1} \mathrm{H}-\mathrm{NMR}$ of $Z$ isomer $\delta=10.07(1 \mathrm{H}, \mathrm{s}), 7.84(1 \mathrm{H}, \mathrm{s}), 7.74(1 \mathrm{H}, \mathrm{d}, J=7.7 \mathrm{~Hz}), 7.25-7.41$ $(2 \mathrm{H}, \mathrm{m}), 4.14(2 \mathrm{H}, \mathrm{q}, J=7.2 \mathrm{~Hz}), 1.18(3 \mathrm{H}, \mathrm{t}, J=7.2 \mathrm{~Hz}) \mathrm{ppm} ;{ }^{13} \mathrm{C}-\mathrm{NMR}$ of $Z$ isomer $\delta=187.62$, $167.50,137.90,135.56,134.06,131.51,130.50,128.95,128.39,127.02,62.04,14.44 \mathrm{ppm}$ $\left(\mathrm{C}_{12} \mathrm{H}_{10} \mathrm{Cl}_{2} \mathrm{O}_{3}\right)$.

Ethyl 3-(4'-Methylphenyl)-3-chloropropenal-2-carboxylate (20d) [1]. Obtained from ethyl 1-(4'methylphenyl)-3-(dimethylamino)prop-2-enone-2-carboxylate (19d) as a pale yellow oil (14\%); bp = $122-123^{\circ} \mathrm{C}$ at $0.3 \mathrm{mmHg} ;{ }^{1} \mathrm{H}-\mathrm{NMR}$ of $Z$ isomer $\delta=9.40(1 \mathrm{H}, \mathrm{s}), 7.43(2 \mathrm{H}, \mathrm{d}, J=8.1 \mathrm{~Hz}), 7.29(2 \mathrm{H}, \mathrm{d}$, $J=8.1 \mathrm{~Hz}), 4.41(2 \mathrm{H}, \mathrm{q}, J=7.2 \mathrm{~Hz}), 2.44(3 \mathrm{H}, \mathrm{s}), 1.40(3 \mathrm{H}, \mathrm{t}, J=7.2 \mathrm{~Hz}) \mathrm{ppm} ;{ }^{13} \mathrm{C}-\mathrm{NMR}$ of $Z$ isomer $\delta=186.48,164.24,155.46,142.94,135.83,131.55,130.29,129.80,62.40,21.70,14.37 \mathrm{ppm}$ $\left(\mathrm{C}_{13} \mathrm{H}_{13} \mathrm{ClO}_{3}\right)$.

Ethyl 3-(4'-Fluorophenyl)-3-chloropropenal-2-carboxylate (20e). Obtained from ethyl 1-(4'-fluorophenyl)-3-(dimethylamino)prop-2-enone-2-carboxylate (19e) as a clear oil (100\%); ${ }^{1} \mathrm{H}-\mathrm{NMR}$ of $Z$ isomer $\delta=10.0(1 \mathrm{H}, \mathrm{s}), 7.47(2 \mathrm{H}, \mathrm{m}), 7.02(2 \mathrm{H}, \mathrm{t}, J=9 \mathrm{~Hz}), 4.02(2 \mathrm{H}, \mathrm{q}, J=7 \mathrm{~Hz}), .98(3 \mathrm{H}, \mathrm{t}, J=7 \mathrm{~Hz})$ $\left(\mathrm{C}_{12} \mathrm{H}_{10} \mathrm{ClFO}_{3}\right)$.

Methyl 3-(4'-Methoxyphenyl)-3-chloropropenal-2-carboxylate (20f). Obtained from methyl 1-(4'methoxyphenyl)-3-(dimethylamino)prop-2-enone-2-carboxylate (19f) as a pale yellow oil (100\%); ${ }^{1} \mathrm{H}-\mathrm{NMR}$ of $Z$ isomer $\delta=9.29(1 \mathrm{H}, \mathrm{s}), 7.39(2 \mathrm{H}, \mathrm{d}, J=9 \mathrm{~Hz}), 6.89(2 \mathrm{H}, \mathrm{d}, J=9 \mathrm{~Hz}), 3.81(3 \mathrm{H}, \mathrm{s}), 3.78$ $(3 \mathrm{H}, \mathrm{s})\left(\mathrm{C}_{12} \mathrm{H}_{11} \mathrm{ClO}_{4}\right)$.

General Preparation of the $\alpha$-Azidoacetophenones 22: To an $\alpha$-bromoacetophenone in DMSO (50 $\mathrm{mL}$ ) was added 4 eq of sodium azide. The solution was stirred at rt. for 20-30 min., then poured into cold $\mathrm{dH}_{2} \mathrm{O}(100 \mathrm{~mL})$ and extracted with ethyl acetate $(3 \times 50 \mathrm{~mL})$. The combined organic layers were 
dried over sodium sulfate. The solution was then slowly evaporated under reduced pressure and the crystals filtered from the concentrated ethyl acetate solution.

2-Azido-4'-chloroacteophenone (22g) [1]. Obtained from 2-bromo-4'-chloroacetophenone (21g) as pale yellow needles $(72 \%) ; \mathrm{mp}=68-69^{\circ} \mathrm{C} ;{ }^{1} \mathrm{H}-\mathrm{NMR} \delta=7.83(2 \mathrm{H}, \mathrm{d}, J=8.3 \mathrm{~Hz}), 7.46(2 \mathrm{H}, \mathrm{d}, J=8.3$ $\mathrm{Hz}), 4.41(2 \mathrm{H}, \mathrm{s}) \mathrm{ppm} ;{ }^{13} \mathrm{C}-\mathrm{NMR} \delta=192.10,140.80,133.06,129.46,129.43,54.97 \mathrm{ppm}$ $\left(\mathrm{C}_{8} \mathrm{H}_{6} \mathrm{ClN}_{3} \mathrm{O}\right)$.

2-Azido-4'-fluoroacteophenone (22i). Obtained from 2-bromo-4'-fluoroacetophenone (21i) as pale yellow needles; $\mathrm{mp}=45^{\circ} \mathrm{C} ;{ }^{1} \mathrm{H}-\mathrm{NMR} \delta=8.0(2 \mathrm{H}, \mathrm{d}, J=8 \mathrm{~Hz}), 7.0(2 \mathrm{H}, \mathrm{d}, J=8 \mathrm{~Hz}), 4.61(2 \mathrm{H}, \mathrm{s}), 3.99$ $(3 \mathrm{H}, \mathrm{s})\left(\mathrm{C}_{8} \mathrm{H}_{6} \mathrm{FN}_{3} \mathrm{O}\right)$.

2-Azido-4'-methoxyacteophenone (22j). Obtained from 2-bromo-4'-methoxyacetophenone (21j) as white needles $(52 \%) ; \mathrm{mp}=71-73{ }^{\circ} \mathrm{C} ;{ }^{1} \mathrm{H}-\mathrm{NMR} \delta=7.99(2 \mathrm{H}, \mathrm{d}, J=9 \mathrm{~Hz}), 7.10(2 \mathrm{H}, \mathrm{d}, J=9 \mathrm{~Hz}), 4.61$ $(2 \mathrm{H}, \mathrm{s}), 3.99(3 \mathrm{H}, \mathrm{s}) ;{ }^{13} \mathrm{C}-\mathrm{NMR} \delta=192.05,164.59,130.58,127.73,114.69,56.04,55.88 \mathrm{ppm}$ $\left(\mathrm{C}_{9} \mathrm{H}_{9} \mathrm{~N}_{3} \mathrm{O}_{2}\right)$.

2-Azido-4'-methylacteophenone (22k). Obtained from 2-bromo-4'-methylacetophenone (21k) as pale yellow needles $(47 \%) ; \mathrm{mp}=71{ }^{\circ} \mathrm{C} ;{ }^{1} \mathrm{H}-\mathrm{NMR} \delta=7.81(2 \mathrm{H}, \mathrm{d}, J=8.2 \mathrm{~Hz}), 7.29(2 \mathrm{H}, \mathrm{d}, J=8.2 \mathrm{~Hz})$, $4.53(2 \mathrm{H}, \mathrm{s}), 2.43(3 \mathrm{H}, \mathrm{s}) ;{ }^{13} \mathrm{C}-\mathrm{NMR} \delta=192.72,145.17,132.00,129.62,128.06,54.80,21.76 \mathrm{ppm}$ $\left(\mathrm{C}_{9} \mathrm{H}_{9} \mathrm{~N}_{3} \mathrm{O}\right)$.

General Preparation of the $\alpha$-Aminoacteophenone PTSA Salts 23: To the $\alpha$-azidoacetophenone in THF $(100 \mathrm{~mL})$ was added leq of triphenylphosphine and 3 eq of pTSA. The solution was stirred at rt. over night. The resulting white solid was filtered and washed with cold THF.

2-Ammonium-4'-chloroacetophenone toulenesulfonate (23g) [1]. Obtained from 2-azido-4'-chloroacetophenone $(\mathbf{2 2 g})$ as a white solid $(81 \%) ; \mathrm{mp}=232-233{ }^{\circ} \mathrm{C} ;{ }^{1} \mathrm{H}-\mathrm{NMR}\left(\mathrm{DMSO}-d_{6}\right): \delta=8.20(3 \mathrm{H}$, br s), $7.99(2 \mathrm{H}, \mathrm{d}, J=8.7 \mathrm{~Hz}), 7.64(2 \mathrm{H}, \mathrm{d}, J=8.7 \mathrm{~Hz}) 7.50(2 \mathrm{H}, \mathrm{d}, J=8.1 \mathrm{~Hz}), 7.11(2 \mathrm{H}, \mathrm{d}, J=8.1 \mathrm{~Hz})$, $4.53(2 \mathrm{H}, \mathrm{s}), 2.28(3 \mathrm{H}, \mathrm{s}) \mathrm{ppm} ;{ }^{13} \mathrm{C}-\mathrm{NMR} \delta=192.22,145.40,139.90,138.42,132.70,130.33,129.49$, $128.45,125.85,45.30,21.02 \mathrm{ppm}\left(\mathrm{C}_{15} \mathrm{H}_{16} \mathrm{ClNO}_{4} \mathrm{~S}\right)$.

2-Ammonium-4'-fluoroacetophenone toulenesulfonate (23i). Obtained from 2-azido-4'-fluoroacetophenone $(\mathbf{2 2 i})$ as a white solid $(76 \%) ; \mathrm{mp}=232{ }^{\circ} \mathrm{C} ;{ }^{1} \mathrm{H}-\mathrm{NMR}\left(\mathrm{DMSO}-d_{6}\right): \delta=8.12(3 \mathrm{H}$, br s), $8.00\left(2 \mathrm{H}, \mathrm{d}\right.$ of d, $\left.J_{H, F}=5.5 \mathrm{~Hz}, J_{H, H}=9.2 \mathrm{~Hz}\right), 7.37(2 \mathrm{H}, \mathrm{d}, \mathrm{J}=8.1 \mathrm{~Hz}), 7.33(2 \mathrm{H}, \mathrm{t}, J=8.9 \mathrm{~Hz}), 7.00$ $(2 \mathrm{H}, \mathrm{d}, J=8.1 \mathrm{~Hz}), 4.50(2 \mathrm{H}, \mathrm{s}), 2.18(3 \mathrm{H}, \mathrm{s}) ;{ }^{13} \mathrm{C}-\mathrm{NMR} \delta=192.04,\left[146.11,137.92\left(\mathrm{~d}, J_{C, F}=618\right.\right.$ $\mathrm{Hz})$ ] , 131.78, 131.65, 130.85, 128.38, 125.84, 116.66, 116.36, 45.21, $21.12 \mathrm{ppm}\left(\mathrm{C}_{15} \mathrm{H}_{16} \mathrm{FNO}_{4} \mathrm{~S}\right)$.

2-Ammonium-4'-methoxyacetophenone toulenesulfonate $\mathbf{( 2 3 j ) . ~ O b t a i n e d ~ f r o m ~ 2 - a z i d o - 4 ' - ~}$ methoxyacetophenone $(\mathbf{2 2} \mathbf{j})$ as a white solid $(68 \%) ; \mathrm{mp}=188-189^{\circ} \mathrm{C} ;{ }^{1} \mathrm{H}-\mathrm{NMR}\left(\mathrm{DMSO}-d_{6}\right): \delta=8.16$ 
(3H, br s), $8.00(2 \mathrm{H}, \mathrm{d}, J=8 \mathrm{~Hz}), 7.47(2 \mathrm{H}, \mathrm{d}, J=8 \mathrm{~Hz}), 7.11(4 \mathrm{H}, \mathrm{d}, J=8 \mathrm{~Hz}), 4.54(2 \mathrm{H}, \mathrm{br} \mathrm{s}), 3.87$ $(3 \mathrm{H}, \mathrm{s}), 2.28(3 \mathrm{H}, \mathrm{s}) ;{ }^{13} \mathrm{C}-\mathrm{NMR} \delta=191.57,164.50,146.09,137.92,130.98,128.38,126.90,125.83$, $114.61,56.10,44.85,21.12 \mathrm{ppm}\left(\mathrm{C}_{16} \mathrm{H}_{19} \mathrm{NO}_{5} \mathrm{~S}\right)$.

2-Ammonium-4'-methylacetophenone toulenesulfonate (23k). Obtained from 2-azido-4'-methylacetophenone (22k) as a white solid $(71 \%) ; \mathrm{mp}=189-191^{\circ} \mathrm{C} ;{ }^{1} \mathrm{H}-\mathrm{NMR}\left(\mathrm{DMSO}-d_{6}\right): \delta=8.09(3 \mathrm{H}, \mathrm{br}$ s), $7.81(2 \mathrm{H}, \mathrm{d}, J=8.1 \mathrm{~Hz}), 7.37(2 \mathrm{H}, \mathrm{d}, J=8.1 \mathrm{~Hz}), 7.29(2 \mathrm{H}, \mathrm{d}, J=8.1 \mathrm{~Hz}), 7.00(2 \mathrm{H}, \mathrm{d}, J=8.1 \mathrm{~Hz})$, $4.46(2 \mathrm{H}, \mathrm{s}), 2.30(3 \mathrm{H}, \mathrm{s}), 2.18(3 \mathrm{H}, \mathrm{s}) ;{ }^{13} \mathrm{C}-\mathrm{NMR} \delta=192.80,146.04,145.58,137.96,131.58,129.89$, $128.62,128.39,125.84,45.11,21.63,21.12 \mathrm{ppm}\left(\mathrm{C}_{16} \mathrm{H}_{19} \mathrm{NO}_{4} \mathrm{~S}\right)$.

General Preparation of the 2-phenacyl-3-phenyl-1H-pyrrole-4-carboxylates 1-15: To the appropriate $\beta$-chloroenal in dry DMF $(30 \mathrm{~mL})$ was added 1.0 eq of the $\alpha$-aminoacetophenone salt. The solution was stirred at $65^{\circ} \mathrm{C}$ for 2 days. The reaction was allowed to cool to rt.. The reaction mixture was added to $\mathrm{dH}_{2} \mathrm{O}(50 \mathrm{~mL})$ and the resulting suspension extracted with ethyl acetate $(2 \times 50 \mathrm{~mL})$. The combined organic layers were dried over sodium sulfate then evaporated under reduced pressure. If the product could not be crystallized from hexanes:ethyl acetate it was purified by flash chromatography (silica gel) with a hexanes:ethyl acetate gradient. The final product was recrystallized from hexanes:ethyl acetate.

Ethyl 2-(4'-Chlorophenacyl)-3-(4'-chlorophenyl)-1H-pyrrole-4-carboxylate (1) [1]. Obtained from 2ammonium-4'-chloroacetophenone toluenesulfonate (23g) and ethyl 3-(4'-chlorophenyl)-3chloropropenal-2-carboxylate (20a) as tan crystals $(4 \%) ; \mathrm{mp}=164-167^{\circ} \mathrm{C} ;{ }^{1} \mathrm{H}-\mathrm{NMR} \delta=9.69(1 \mathrm{H}$, br s), $7.73(1 \mathrm{H}, \mathrm{d}, J=3.4 \mathrm{~Hz}), 7.24(2 \mathrm{H}, \mathrm{d}, J=6.7 \mathrm{~Hz}), 7.04(2 \mathrm{H}, \mathrm{d}, J=6.1 \mathrm{~Hz}), 7.00(2 \mathrm{H}, \mathrm{d}, J=6.7 \mathrm{~Hz})$, $6.98(2 \mathrm{H}, \mathrm{d}, J=6.1 \mathrm{~Hz}), 4.17(2 \mathrm{H}, \mathrm{q}, J=7.2 \mathrm{~Hz}), 1.18(3 \mathrm{H}, \mathrm{t}, J=7.2 \mathrm{~Hz}) \mathrm{ppm} ;{ }^{13} \mathrm{C}-\mathrm{NMR} \delta=186.48$, 163.74, 138.37, 135.83, 134.09, 132.73, 132.08, 131.88, 130.44, 130.03, 128.92, 128.21, 127.66, 117.64, 60.36, 14.43 ppm. Anal. calcd for $\mathrm{C}_{20} \mathrm{H}_{15} \mathrm{Cl}_{2} \mathrm{NO}_{3}: \mathrm{C}, 61.87 ; \mathrm{H}, 3.89 ; \mathrm{N}, 3.61$. Found: $\mathrm{C}, 61.94$; $\mathrm{H}, 3.68 ; \mathrm{N}, 3.47$.

Ethyl 2-(Phenacyl)-3-(4'-bromophenyl)-1H-pyrrole-4-carboxylate (2) [1]. Obtained from 2-aminoacetophenone hydrochloride (23h) and ethyl 3-(4'-bromophenyl)-3-chloropropenal-2-carboxylate (20b) as tan crystals $(17 \%) ; \mathrm{mp}=152-154^{\circ} \mathrm{C} ;{ }^{1} \mathrm{H}-\mathrm{NMR} \delta=9.72(1 \mathrm{H}, \mathrm{br} \mathrm{s}), 7.69(1 \mathrm{H}, \mathrm{d}, J=3.4 \mathrm{~Hz}), 7.24$ $(2 \mathrm{H}, \mathrm{d}, J=7.4 \mathrm{~Hz}), 7.21(2 \mathrm{H}, \mathrm{d}, J=7.4 \mathrm{~Hz}), 7.07(2 \mathrm{H}, \mathrm{m}, J=8.5 \mathrm{~Hz}), 6.99(2 \mathrm{H}, \mathrm{t}, J=7.4 \mathrm{~Hz}), 6.86$ $(2 \mathrm{H}, \mathrm{d}, J=8.5 \mathrm{~Hz}), 4.11(2 \mathrm{H}, \mathrm{q}, J=7.2 \mathrm{~Hz}), 1.14(3 \mathrm{H} \mathrm{t}, J=7.2 \mathrm{~Hz}) \mathrm{ppm} ;{ }^{13} \mathrm{C}-\mathrm{NMR} \delta=187.98$, 163.97, 137.34, 133.07, 132.42, 132.15, 131.86, 130.48, 130.12, 129.13, 128.91, 128.00, 121.86, $117.23,60.45,14.56$ ppm. Anal calcd for $\mathrm{C}_{20} \mathrm{H}_{16} \mathrm{BrNO}_{3}$ : C, 60.32; H, 4.05; N, 3.52. Found: $\mathrm{C}, 60.03$; $\mathrm{H}, 3.82 ; \mathrm{N}, 3.55$.

Ethyl 2-(Phenacyl)-3-(3'-chlorophenyl)-1H-pyrrole-4-carboxylate (3) [1]. Obtained from 2-aminoacetophenone hydrochloride (23h) and ethyl 3-(3'-chlorophenyl)-3-chloropropenal-2-carboxylate (20c) as pale yellow crystals $(6 \%) ; \mathrm{mp}=135-137^{\circ} \mathrm{C} ;{ }^{1} \mathrm{H}-\mathrm{NMR} \delta=9.95(1 \mathrm{H}, \mathrm{br} \mathrm{s}), 7.73(1 \mathrm{H}, \mathrm{d}, J=3.6 \mathrm{~Hz})$, 
$7.32(2 \mathrm{H}, \mathrm{d}, J=8.1 \mathrm{~Hz}), 7.23(2 \mathrm{H}, \mathrm{t}, J=7.5 \mathrm{~Hz}), 6.99-7.11(4 \mathrm{H}, \mathrm{m}), 6.88-6.98(2 \mathrm{H}, \mathrm{m}), 4.15(2 \mathrm{H}, \mathrm{q}, J$ $=7.2 \mathrm{~Hz}), 1.16(3 \mathrm{H}, \mathrm{t}, J=7.2 \mathrm{~Hz}) \mathrm{ppm} ;{ }^{13} \mathrm{C}-\mathrm{NMR} \delta=187.98,163.90,137.60,135.47,133.27,131.67$, $130.28,129.66,129.01,128.93,128.86,128.45,127.97,127.89,127.42,117.62,60.32,14.35$ ppm. Anal calcd for $\mathrm{C}_{20} \mathrm{H}_{16} \mathrm{ClNO}_{3}$ : C, 67.90; H, 4.56; N, 3.96. Found: C, 67.82; H, 4.46; N, 3.94 .

Ethyl 2-(4'-Fluorophenacyl)-3-(4'-methylphenyl)-1H-pyrrole-4-carboxylate (4). Obtained from 2ammonium-4'-fluoroacetophenone toluenesulfonate (23i) and ethyl 3-(4'-methylphenyl)-3-chloropropenal-2-carboxylate (20d) as a white solid $(18 \%) ; \mathrm{mp}=112-115^{\circ} \mathrm{C} ;{ }^{1} \mathrm{H}-\mathrm{NMR} \delta=9.61(1 \mathrm{H}$, br s), $7.64(1 \mathrm{H}, \mathrm{d}, J=4 \mathrm{~Hz}), 7.26\left(2 \mathrm{H}, \mathrm{d}\right.$ of d, $\left.J_{H, F}=5 \mathrm{~Hz}, J_{H, H}=9 \mathrm{~Hz}\right), 6.87(2 \mathrm{H}, \mathrm{d}, J=9 \mathrm{~Hz}), 6.77(2 \mathrm{H}, \mathrm{d}, J$ $=9 \mathrm{~Hz}), 6.59(2 \mathrm{H}, \mathrm{t}, J=9 \mathrm{~Hz}), 4.09(2 \mathrm{H}, \mathrm{q}, J=7 \mathrm{~Hz}), 2.16(3 \mathrm{H}, \mathrm{s}), 1.11(3 \mathrm{H}, \mathrm{t}, J=7 \mathrm{~Hz}) ;{ }^{13} \mathrm{C}-\mathrm{NMR} \delta$ $=164.00,137.37,131.43,131.61,13172,130.51,130.01,129.51,128.70,128.12,117.14,117.56$, $115.30,115.26,114.88,114.58,60.16,21.29,14.43$ ppm. Anal calcd for $\mathrm{C}_{21} \mathrm{H}_{18} \mathrm{FNO}_{3}$ : C, 71.78; $\mathrm{H}$, 5.16; N, 3.99. Found: C, 71.57; H, 5.21; N, 4.11.

Ethyl 2-(4'-Chlorophenacyl)-3-(4'-methylphenyl)-1H-pyrrole-4-carboxylate (5) [1]. The title compound was obtained from 2-ammonium-4'-chloroacetophenone toluenesulfonate (23g) and ethyl 3-(4'-methylphenyl)-3-chloropropenal-2-carboxylate (20d) as white crystals $(15 \%)$; $\mathrm{mp}=155-157^{\circ} \mathrm{C}$; ${ }^{1} \mathrm{H}-\mathrm{NMR} \delta=9.66(1 \mathrm{H}$, br s), $7.64(1 \mathrm{H}, \mathrm{d}, J=3.6 \mathrm{~Hz}), 7.14(2 \mathrm{H}, \mathrm{d}, J=8.7 \mathrm{~Hz}), 6.88(2 \mathrm{H}, \mathrm{d}, J=8.7$ $\mathrm{Hz}), 6.84(2 \mathrm{H}, \mathrm{d}, J=8.0 \mathrm{~Hz}), 6.77(2 \mathrm{H}, \mathrm{d}, J=8.0 \mathrm{~Hz}), 4.09(2 \mathrm{H}, \mathrm{q}, J=7.2 \mathrm{~Hz}), 2.18(3 \mathrm{H}, \mathrm{s}), 1.11(3 \mathrm{H}$, $\mathrm{t}, J=7.2 \mathrm{~Hz}) \mathrm{ppm} ;{ }^{13} \mathrm{C}-\mathrm{NMR} \delta=186.83,163.94,137.74,137.57,136.05,133.88,131.38,130.45$, $130.25,130.02,128.90,128.13,127.93,117.60,60.19,21.30,14.44$ ppm. Anal calcd for $\mathrm{C}_{21} \mathrm{H}_{18} \mathrm{ClNO}_{3}$ : C, 68.57; H, 4.93; N, 3.81. Found: C, 68.25; H, 4.81; N, 3.77.

Ethyl N-Methyl-4-(4'-chlorophenyl)-pyrrole-2-carboxylate (6) [35]. The 2-(4'-chlorophenyl) vinamidinium salt was synthesized from 3 eq of phosphorous oxychloride in dry DMF to which 4'-chlorophenylacetic acid was slowly added. After refluxing for $3.5 \mathrm{hr}$., $\mathrm{dH}_{2} \mathrm{O}(100 \mathrm{~mL})$ and $\mathrm{NaClO}_{4}$ $(20 \mathrm{~g})$ was added to the $\mathrm{rt}$ solution. The resulting tan crystals $(98 \%)$ were filtered and washed with $20 \% \mathrm{NaClO}_{4} ;{ }^{1} \mathrm{H}-\mathrm{NMR} \delta=7.73(2 \mathrm{H}, \mathrm{s}), 7.51(2 \mathrm{H}, \mathrm{d}, J=8.5 \mathrm{~Hz}), 7.34(2 \mathrm{H}, \mathrm{d}, J=8.5 \mathrm{~Hz}), 3.25,(6 \mathrm{H}$, s), $2.46(6 \mathrm{H}, \mathrm{s}) \mathrm{ppm} ;{ }^{13} \mathrm{C}-\mathrm{NMR} \delta=206.9,206.6,164.7,135.5,135.2,132.7,129.5,105.5,49.4,40.4$ ppm. The title compound was synthesized from 2-(4'-chlorophenyl) vinamidinium salt, ethyl sarcosinate and $\mathrm{NaH}$. To 4.4 eq of hexane-washed $\mathrm{NaH}$ in dry DMF under $\mathrm{N}_{2}(\mathrm{~g})$ was added 1.5 eq of ethyl sarcosinate hydrochloride and the mixture was stirred for $15 \mathrm{~min}$. at rt. Then the 2-(4'chlorophenyl) vinamidinium salt was added and the solution was stirred at $\mathrm{rt}$ for $45 \mathrm{~min}$, then refluxed for $2.5 \mathrm{hr}$. The DMF was removed under reduced pressure. The crude pyrrole was taken up in EtOAc and washed with water $(100 \mathrm{~mL})$, then brine $(100 \mathrm{~mL})$. The product was purified by passing a solution of the pyrrole in $\mathrm{CHCl}_{3}$ through a short plug of silica gel followed by recrystallization from hexanes:EtOAc yielding a light yellow solid $(100 \%) ; \mathrm{mp}=66-67^{\circ} \mathrm{C} ;{ }^{1} \mathrm{H}-\mathrm{NMR} \delta=7.40(2 \mathrm{H}, \mathrm{d}, J=8.5$ $\mathrm{Hz}), 7.29(2 \mathrm{H}, \mathrm{d}, J=8.5 \mathrm{~Hz}), 7.18(2 \mathrm{H}, \mathrm{d}, J=7 \mathrm{~Hz}), 7.03(2 \mathrm{H}, \mathrm{d}, J=7 \mathrm{~Hz}), 4.31(2 \mathrm{H}, \mathrm{q}, J=7.2 \mathrm{~Hz})$, $3.95(3 \mathrm{H}, \mathrm{s}), 1.37(3 \mathrm{H}, \mathrm{t}, J=7.2 \mathrm{~Hz}) \mathrm{ppm} ;{ }^{13} \mathrm{C}-\mathrm{NMR} \delta=161.20,133.09,131.61,128.84,126.26$, 
126.02, 123.69, 122.82, 114.64, 60.03, 37.00, 14.46 ppm. Anal calcd for $\mathrm{C}_{14} \mathrm{H}_{14} \mathrm{ClNO}_{2}: \mathrm{C}, 63.76 ; \mathrm{H}$, 5.35; N, 5.31. Found: C, 63.68; H, 5.12; N, 5.09.

Ethyl 2-(4'-Fluorophenacyl)-3-(4'-Fluorophenyl)-1H-pyrrole-4-carboxylate (7). Obtained from 2ammonium-4'-fluoroacetophenone toluenesulfonate (23i) and ethyl 3-(4'-fluorophenyl)-3-chloropropenal-2-carboxylate (20e) as a white solid (9\%); $\mathrm{mp}=141{ }^{\circ} \mathrm{C} ;{ }^{1} \mathrm{H}-\mathrm{NMR} \delta=10.11$ (1H, br s), 7.77 $(1 \mathrm{H}, \mathrm{d}, J=3.6 \mathrm{~Hz}), 7.37\left(2 \mathrm{H}, \mathrm{d}\right.$ of d, $\left.J_{H, F}=5.5 \mathrm{~Hz}, J_{H, H}=9.8 \mathrm{~Hz},\right), 7.05\left(2 \mathrm{H}, \mathrm{d}\right.$ of d, $J_{H, F}=5.3 \mathrm{~Hz}, J_{H, H}$ $=9.6 \mathrm{~Hz},) 6.77(2 \mathrm{H}, \mathrm{t}, J=8.5 \mathrm{~Hz}), 6.74(2 \mathrm{H}, \mathrm{t}, J=8.5 \mathrm{~Hz}), 4.18(2 \mathrm{H}, \mathrm{q}, J=7.2 \mathrm{~Hz}), 1.20(3 \mathrm{H}, \mathrm{t}, J=$ $7.2 \mathrm{~Hz}) ;{ }^{13} \mathrm{C}-\mathrm{NMR} \delta=186.33,\left[166.30,162.94\left(\mathrm{~d}, J_{C, F}=254 \mathrm{~Hz}\right)\right], 163.67,\left[163.85,160.57\left(\mathrm{~d}, J_{C, F}=\right.\right.$ $247 \mathrm{~Hz})$ ], 133.20, 133.16, $132.82\left(\mathrm{~d}, J_{C, F}^{2}=8 \mathrm{~Hz}\right), 132.01,131.45\left(\mathrm{~d}, J_{C, F}^{2}=9 \mathrm{~Hz}\right), 129.65,128.90$, $114.70\left(\mathrm{~d}, J_{C, F}^{3}=22 \mathrm{~Hz}\right.$ ppm), $114.13,\left(\mathrm{~d}, J_{C, F}^{3}=21 \mathrm{~Hz}\right), 60.06,14.17 \mathrm{ppm} ; \mathrm{SFC} / \mathrm{MS}:(\mathrm{M}+\mathrm{H})^{+} \mathrm{m} / z$ 356. Anal calcd for $\mathrm{C}_{20} \mathrm{H}_{15} \mathrm{~F}_{2} \mathrm{NO}_{3}$ : C, 67.60; H, 4.25; N, 3.94. Found: C, 67.56; H, 3.99; N, 3.91 .

Ethyl 2-(4'-Methoxyphenacyl)-3-(4'-Chlorophenyl)-1H-pyrrole-4-carboxylate (8). Obtained from 2ammonium-4'-methoxyacetophenone toluenesulfonate (23j) and ethyl 3-(4'-chlorophenyl)-3-chloropropenal-2-carboxylate (20a) as tan crystals $(12 \%) ; \mathrm{mp}=105^{\circ} \mathrm{C} ;{ }^{1} \mathrm{H}-\mathrm{NMR} \delta=9.84(1 \mathrm{H}$, br s), 7.74 $(1 \mathrm{H}, \mathrm{d}, J=3.6 \mathrm{~Hz}), 7.34(2 \mathrm{H}, \mathrm{d}, J=8.8 \mathrm{~Hz}), 7.04(4 \mathrm{H}, \mathrm{s}), 6.55(2 \mathrm{H}, \mathrm{d}, J=8.8 \mathrm{~Hz}), 4.19(2 \mathrm{H}, \mathrm{q}, J=$ $7.2 \mathrm{~Hz}), 1.22(3 \mathrm{H}, \mathrm{t}, J=7.2 \mathrm{~Hz}) ;{ }^{13} \mathrm{C}-\mathrm{NMR} \delta=186.36,163.74,162.61,133.07,132.56,131.91$, $131.33,130.93,129.99,129.25,128.20,127.24,116.56,112.94,60.01,55.45,14.21 \mathrm{ppm}$; SFC/MS: $(\mathrm{M}+\mathrm{H})^{+} \mathrm{m} / \mathrm{z}$ 384; HRMS-CI calcd for $\mathrm{C}_{21} \mathrm{H}_{18} \mathrm{ClNO}_{4}(\mathrm{M}+\mathrm{Na})^{+} m / z 406.0817$ found 406.0811 .

Ethyl 2-(4'-Chlorophenacyl)-3-(4'-Fluorophenyl)-1H-pyrrole-4-carboxylate (9). Obtained from 2ammonium-4'-chloroacetophenone toluenesulfonate (23g) and ethyl 3-(4'-fluorophenyl)-3-chloropropenal-2-carboxylate (20e) as a tan solid (8\%); $\mathrm{mp}=133{ }^{\circ} \mathrm{C} ;{ }^{1} \mathrm{H}-\mathrm{NMR} \delta=9.97(1 \mathrm{H}$, br s), $7.77(1 \mathrm{~h}$, $\mathrm{d}, J=3.6 \mathrm{~Hz}), 7.26(2 \mathrm{H}, \mathrm{d}, J=8.8 \mathrm{~Hz}), 7.03(4 \mathrm{H}, \mathrm{m}), 6.77(2 \mathrm{H}, \mathrm{t}, J=8.7 \mathrm{~Hz}), 4.18(2 \mathrm{H}, \mathrm{q}, J=7.2 \mathrm{~Hz})$, $1.20(3 \mathrm{H}, \mathrm{t}, J=7.2 \mathrm{~Hz}) ;{ }^{13} \mathrm{C}-\mathrm{NMR} \delta=186.39,163.60,\left[137.85,135.33\left(\mathrm{~d}, J_{C, F}=190 \mathrm{~Hz}\right)\right], 132.82$, $132.71,132.16,130.25,129.59,128.94,128.84,127.80,116.97,114.30,114.01,60.08,14.16$ ppm; SFC/MS: $(\mathrm{M}+\mathrm{H})^{+} \mathrm{m} / z$ 372; HRMS-CI calcd for $\mathrm{C}_{20} \mathrm{H}_{15} \mathrm{ClFNO}_{3}(\mathrm{M}+\mathrm{Na})^{+} \mathrm{m} / z 394.0617$ found 394.0619 .

Methyl 2-(4'-Methylphenacyl)-3-(4'-methoxyphenyl)-1H-pyrrole-4-carboxylate (10). Obtained from 2ammonium-4'-methylacetophenone toluenesulfonate (23k) and methyl 3-(4'-methoxyphenyl)-3chloropropenal-2-carboxylate (20f) as tan crystals $(11 \%) ; \mathrm{mp}=185-189^{\circ} \mathrm{C} ;{ }^{1} \mathrm{H}-\mathrm{NMR} \delta=10.10(1 \mathrm{H}$, br s), $7.81(2 \mathrm{H}, \mathrm{d}, J=8 \mathrm{~Hz}), 7.65(2 \mathrm{H}, \mathrm{d}, J=9 \mathrm{~Hz}), 7.37(1 \mathrm{H}, \mathrm{d}, J=3.5 \mathrm{~Hz}), 7.31(2 \mathrm{H}, \mathrm{d}, J=8 \mathrm{~Hz})$, $6.96(2 \mathrm{H}, \mathrm{d}, J=9 \mathrm{~Hz}), 3.85(3 \mathrm{H}, \mathrm{s}), 3.77(3 \mathrm{H}, \mathrm{s}), 2.45(3 \mathrm{H}, \mathrm{s}) ;{ }^{13} \mathrm{C}-\mathrm{NMR} \delta=184.53,164.57,160.56$, 143.08, 142.54, 134.91, 130.65, 129.73, 129.19, 128.76, 126.02, 122.83, 122.00, 113.77, 55.34, 51.24, 21.66 ppm; SFC/MS: $(\mathrm{M}+\mathrm{H})^{+} \mathrm{m} / z$ 350; HRMS-CI calcd for $\mathrm{C}_{21} \mathrm{H}_{19} \mathrm{NO}_{4}(\mathrm{M}+\mathrm{Na})^{+} \mathrm{m} / z 372.1207$ found 372.1212 . 
Methyl 2-(4'-Methoxyphenacyl)-3-(4'-methoxyphenyl)-1H-pyrrole-4-carboxylate (11). Obtained from 2-ammonium-4'-methoxyacetophenone toluenesulfonate (23j) and methyl 3-(4'-methoxyphenyl)-3chloropropenal-2-carboxylate (20f) as tan crystals $(6 \%) ; \mathrm{mp}=166^{\circ} \mathrm{C} ;{ }^{1} \mathrm{H}-\mathrm{NMR} \delta=10.03(1 \mathrm{H}$, br s), $7.71(1 \mathrm{H}, \mathrm{d}, J=3.6 \mathrm{~Hz}), 7.37(2 \mathrm{H}, \mathrm{d}, J=8.8 \mathrm{~Hz}), 7.03(2 \mathrm{H}, \mathrm{d}, J=8.8 \mathrm{~Hz}), 6.61(2 \mathrm{H}, \mathrm{d}, J=8.8 \mathrm{~Hz})$, $6.53(2 \mathrm{H}, \mathrm{d}, J=8.8 \mathrm{~Hz}), 3.73(3 \mathrm{H}, \mathrm{s}), 3.72(3 \mathrm{H}, \mathrm{s}), 3.71(3 \mathrm{H}, \mathrm{s}) ;{ }^{13} \mathrm{C}-\mathrm{NMR} \delta=186.71,164.34,162.34$, $158.83,132.43,132.31,131.47,129.92,129.54,128.34,125.41,116.01,112.83,112.79,55.31,55.18$, 51.08 ppm; SFC/MS: $(\mathrm{M}+\mathrm{H})^{+} \mathrm{m} / z$ 366. Anal calcd for $\mathrm{C}_{21} \mathrm{H}_{19} \mathrm{NO}_{5}$ : C, 69.03; H, 5.24; N, 3.83. Found: C, 68.74; H, 4.98; N, 3.65 .

Methyl 2-(4'-Chlorophenacyl)-3-(4'-methoxyphenyl)-1H-pyrrole-4-carboxylate (12). Obtained from 2ammonium-4'-chloroacetophenone toluenesulfonate (23g) and methyl 3-(4'-methoxyphenyl)-3-chloropropenal-2-carboxylate (20f) as tan crystals $(6 \%) ; \mathrm{mp}=189^{\circ} \mathrm{C} ;{ }^{1} \mathrm{H}-\mathrm{NMR} \delta=9.77(1 \mathrm{H}$, br s), 7.74 $(1 \mathrm{H}, \mathrm{d}, J=3.6 \mathrm{~Hz}), 7.24(2 \mathrm{H}, \mathrm{d}, J=8.8 \mathrm{~Hz}), 7.00(2 \mathrm{H}, \mathrm{d}, J=8.8 \mathrm{~Hz}), 6.96(2 \mathrm{H}, \mathrm{d}, J=8.8 \mathrm{~Hz}), 6.59$ $(2 \mathrm{H}, \mathrm{d}, J=8.8 \mathrm{~Hz}), 3.73(3 \mathrm{H}, \mathrm{s}), 3.72(3 \mathrm{H}, \mathrm{s}) ;{ }^{13} \mathrm{C}-\mathrm{NMR} \delta=186.52,164.07,159.24,137.36,135.53$, 133.34, 132.32, 130.24, 129.59, 128.88, 127.67, 124.78, 116.47, 112.87, 55.33, 51.17 ppm; SFC/MS: $(\mathrm{M}+\mathrm{H})^{+} \mathrm{m} / z$ 370; HRMS-CI calcd for $\mathrm{C}_{20} \mathrm{H}_{16} \mathrm{ClNO}_{4}(\mathrm{M}+\mathrm{Na})^{+} \mathrm{m} / z 392.0660$ found 392.0657 .

2-(4'-methoxyphenacyl)-3,4-bis(4'-methoxyphenyl)-1H-pyrrole (13) [3]. Obtained from 2-ammonium4'-methoxyacetophenone toluenesulfonate (23j) and 2,3-bis(4'-methoxyphenyl)-3-chloropropenal as tan crystals $(93 \%) ; \mathrm{mp}=77-79^{\circ} \mathrm{C} ;{ }^{1} \mathrm{H}-\mathrm{NMR} \delta=9.45(1 \mathrm{H}, \mathrm{br} \mathrm{s}), 7.40(2 \mathrm{H}, \mathrm{d}, J=8.8 \mathrm{~Hz}), 7.15(1 \mathrm{H}, \mathrm{d}, J$ $=2.9 \mathrm{~Hz}), 7.00(2 \mathrm{H}, \mathrm{d}, J=8.8 \mathrm{~Hz}), 6.80(2 \mathrm{H}, \mathrm{d}, J=8.8 \mathrm{~Hz}), 6.75(2 \mathrm{H}, \mathrm{d}, J=8.8 \mathrm{~Hz}), 6.54(2 \mathrm{H}, \mathrm{d}, J=8.8$ $\mathrm{Hz}), 6.52(2 \mathrm{H}, \mathrm{d}, J=8.8 \mathrm{~Hz}), 3.78(3 \mathrm{H}, \mathrm{s}), 3.72,(3 \mathrm{H}, \mathrm{s}), 3.70(3 \mathrm{H}, \mathrm{s}) ;{ }^{13} \mathrm{C}-\mathrm{NMR} \delta=186.7,162.3$, $158.4,132.6,131.7,130.6,129.9,129.6,129.3,127.4,122.0,113.9,113.8,113.5,113.0,55.4,55.3$ ppm; HRMS-EI calcd for $\mathrm{C}_{26} \mathrm{H}_{24} \mathrm{NO}_{4}\left(\mathrm{M}^{+}\right) \mathrm{m} / z$ 414.1705. Found 414.1693.

Methyl 3,4-bis(3',4'-dimethoxyphenyl)-1H-pyrrole-2-carboxylate (14) [36]. Obtained from methyl glycinate hydrochloride, 2,3-bis(3',4'-dimethoxyphenyl)-3-chloropropenal and DABCO in toluene as tan crystals $(92 \%) ; \mathrm{mp}=66-68^{\circ} \mathrm{C} ;{ }^{1} \mathrm{H}-\mathrm{NMR} \delta=3.58(3 \mathrm{H}, \mathrm{s}), 3.73(3 \mathrm{H}, \mathrm{s}), 3.75(3 \mathrm{H}, \mathrm{s}), 3.84(3 \mathrm{H}, \mathrm{s})$, $3.89(3 \mathrm{H}, \mathrm{s}), 6.57(1 \mathrm{H}$, br s) $, 6.74(2 \mathrm{H}, \mathrm{br} \mathrm{s}), 6.83(3 \mathrm{H}$, br s), $7.08(1 \mathrm{H}, \mathrm{d}, J=3 \mathrm{~Hz})$ and $9.16(1 \mathrm{H}$, broad $\mathrm{s}) ;{ }^{13} \mathrm{C}-\mathrm{NMR} \delta=51.3,55.5,55.8,55.9,56.0,110.6,111.1,111.9,114.4,119.4,120.0,120.3,123.3$, 126.5, 126.9, 127.3, 129.0, 147.4, 148.0, 148.1, 148.4 and 161.6; FTIR (neat) 3320 and $1685 \mathrm{~cm}-1$; HRMS-EI calcd for $\mathrm{C}_{22} \mathrm{H}_{23} \mathrm{NO}_{6}\left(\mathrm{M}^{+}\right) \mathrm{m} / z 397.1525$ found 397.1514 .

Ethyl N-Methyl 3,4-bis(3',4'-dimethoxyphenyl)-pyrrole-2-carboxylate (15). In a 250mL flask was placed 3'chloro-2'3'-bis-(3,4-dimethoxyphenyl)-2-propeneal $(0.250 \mathrm{~g}, 0.690 \mathrm{mmol})$ and dry toluene $(100 \mathrm{~mL})$. Once the solution became homogeneous, sarcosine ethyl ester hydrochloride $(0.317 \mathrm{~g}$, $2.07 \mathrm{mmol})$ and DABCO $(0.115 \mathrm{~g}, 1.03 \mathrm{mmol})$ was added. The stirring solution was heated to reflux for 24 hours under $\mathrm{N}_{2}$. The reaction mixture was allowed to cool to room temperature and the organic layer was washed 3 times with water $(50 \mathrm{~mL})$, once with brine $(50 \mathrm{~mL})$, dried over $\mathrm{Mg}_{2} \mathrm{SO}_{4}$, filtered and concentrated in vacuo to give $310 \mathrm{mg}$ of a dark yellow brown oil which was purified by automated 
flash chromatography (ethyl acetate/hexanes) by a slow gradient elution. An analytically pure sample was prepared by recrystalization from methanol/water to yield a yellow solid $(114 \mathrm{mg}, 38.9 \%) ; \mathrm{mp}=$ 143-144 ${ }^{\circ} \mathrm{C} ;{ }^{1} \mathrm{H}-\mathrm{NMR} \delta=6.93(1 \mathrm{H}, \mathrm{s}), 6.74-6.83(4 \mathrm{H}, \mathrm{m}), 6.72(1 \mathrm{H}, \mathrm{s}), 6.55(1 \mathrm{H}, \mathrm{s}), 4.09(2 \mathrm{H}, \mathrm{q}, J=$ $7.2 \mathrm{~Hz}), 3.98(3 \mathrm{H}, \mathrm{s}), 3.88(3 \mathrm{H}, \mathrm{s}), 3.93(3 \mathrm{H}, \mathrm{s}), 3.75(3 \mathrm{H}, \mathrm{s}), 3.56(3 \mathrm{H}, \mathrm{s}), 1.01(3 \mathrm{H}, \mathrm{t}, J=7.2 \mathrm{~Hz})$;

${ }^{13} \mathrm{C}-\mathrm{NMR} \delta=161.82,148.37,148.17,147.82,147.24,130.52,128.87,127.41,126.26,123.85,123.09$, 120.70, 119.86, 114.38, 111.64, 111.08, 110.59, 59.66, 55.95, 55.87, 55.82, 55.44, 37.54, 13.93; FT-IR (neat) $3110 \mathrm{~cm}^{-1}, 2924 \mathrm{~cm}^{-1}, 2831 \mathrm{~cm}^{-1}, 1689 \mathrm{~cm}^{-1}, 1413 \mathrm{~cm}^{-1}, 1227 \mathrm{~cm}^{-1}$; HRMS-EI calc for $\mathrm{C}_{24} \mathrm{H}_{27} \mathrm{NO}_{6}\left(\mathrm{M}^{+}\right) \mathrm{m} / z 425.1838$ found 425.1859 .

\section{Hypolipidemic Studies.}

CF-1 male mice and Sprague-Dawley male were purchased from Harlan (Indianapolis, IN) and acclimated to their new environment for at least 14 days prior to the start of any studies. Animals were housed in $12 \mathrm{~h}$ light-dark cycles at $68^{\circ} \mathrm{F}$. Food (5015 mouse diet or 5012 rat diet, PMI Nutrition International) and water were given ad libitum. Healthy CF-1 male mice $(\sim 35 \mathrm{~g})$ were administered I.P. $2-8 \mathrm{mg} / \mathrm{kg}$ of the pyrrole derivatives $3-15,90 \mathrm{mg} / \mathrm{kg} /$ day of gemfibrozil (Teva), $8 \mathrm{mg} / \mathrm{kg} /$ day of atorvastatin (Pfizer), or $12.5 \mathrm{mg} / \mathrm{kg} /$ day of niacin (Sigma) dissolved in $1 \%$ CMC daily for 14 days. These dosage levels represent the therapuetic doses for the known drugs. The pyrroles were administered at the dosage range of the statins. Blood $(\sim 0.5 \mathrm{~mL})$ was collected on day 7 from the suborbital vein under $\mathrm{CO}_{2}$ anesthesia. The mice were euthanatized with $\mathrm{CO}_{2}$ after 14 days upon completion of the study.

Healthy Sprague-Dawley male rats ( $400 \mathrm{~g})$ were administered by gavage $2 \mathrm{mg} / \mathrm{kg}$ of the pyrrole derivatives 1 or $2,90 \mathrm{mg} / \mathrm{kg} /$ day of gemfibrozil (Teva), or $8 \mathrm{mg} / \mathrm{kg} /$ day of atorvastatin (Pfizer) dissolved in $1 \% \mathrm{CMC}$ daily for 14 days. Blood $(\sim 0.5 \mathrm{~mL})$ was collected on day 7 from the suborbital vein under $\mathrm{CO}_{2}$ anesthesia. Blood $(\sim 10 \mathrm{~mL})$ was collected from the abdominal vein of pentobarbitalanesthetized drug-treated Sprague-Dawley rats. The rats were euthanatized with pentobarbital-KCl I.P. after 14 days upon completion of the study. Body weights, organ weights and daily food consumption of rats were determined as previously reported [22].

Serum was separated by centrifugation at $5000 \mathrm{rpm} \times 3 \mathrm{~min}$. Total serum cholesterol (Infinity ${ }^{\mathrm{R}}$ ), triglyceride $\left(\right.$ Infinity $^{\mathrm{R}}$ ), HDL-cholesterol (HDL-C Plus ${ }^{\mathrm{R}}$ ) and LDL-cholesterol (LDL-C Plus ${ }^{\mathrm{R}}$ ) concentrations were determined by commercial enzymatic assays (ThermoDMA, Louisville, CO) and analyzed on a Perkin-Elmer $\lambda-25 \mathrm{UV}-\mathrm{Vis}$ spectrometer.

Rat liver, small intestine, and fecal materials ( $24 \mathrm{~h}$ collection) were removed and lipids extracted [37]. To $2 \mathrm{~mL}$ of a $10 \%$ tissue homogenate in $10 \%$ sucrose $/ 1 \mathrm{mM}$ EDTA was added $6 \mathrm{~mL}$ of 1:2 $\mathrm{CHCl}_{3}: \mathrm{CH}_{3} \mathrm{OH}$, then mixed via a vortex for $30 \mathrm{sec}$. and let stand for few minutes. An additional $2 \mathrm{~mL}$ of $\mathrm{CHCl}_{3}$ was added to each tube and vortexed for $30 \mathrm{sec}$. The $\mathrm{CHCl}_{3}$ layer was removed and allowed to evaporate yielding the lipid residue. The lipid residue was dissolved in $200 \mu \mathrm{L}$ of $\mathrm{CHCl}_{3}$. The total cholesterol and triglyceride concentrations of the lipid extracts were determined as described above. 
Statistical Analysis.

Data is displayed in tables and figures as the means \pm standard deviations of the mean expressed as a percentage of the control value. $N$ is the number of samples per group. The Student's " $t$ "-test was used to determine the probable level of significance $(p)$ between test samples and control samples. Values of $p<0.05$ were considered to be significant.

\section{References}

1. Evans, M.A.; Smith, D.C.; Holub, J.M.; Argenti, A.; Hoff, M.; Dalglish, G.A.; Wilson, D.L.; Taylor, B.M.; Berkowitz, J.D.; Burnham, B.S.; Krumpe, K.; Gupton, J.T.; Scarlett, T.C.; Durham, R.; Hall, I.H. "Synthesis and Cytotoxicity of Substituted Ethyl 2-phenacyl-3-phenylpyrrole-4carboxylates." Arch. Pharm. Pharm. Med. Chem. 2003, 336, 181-190.

2. Burnham, B.S.; Gupton, J.T.; Krumpe, K.E.; Webb, T.; Shuford, J.; Bowers, B.; Warren, A.E.; Barnes, C.; Hall, I.H. "Cytotoxicity of Substituted Alkyl-3,4-bis(4-methoxyphenyl)pyrrole-2carboxylates in L1210 Lymphoid Leukemia Cells." Arch. Pharm. Pharm. Med. Chem. 1998, 331, 337-341.

3. Gupton, J.T.; Burnham, B.S.; Byrd, B.D.; Krumpe, K.E.; Stokes, C.; Shuford, J.; Winkle, S.; Webb, T.; Warren, A.E.; Barnes, C.; Henry, J.; Hall, I.H. "The Cytotoxicity and Mode of Action of 2,3,4-Trisubstituted Pyrroles and Related Derivatives in Human Tmolt 4 Leukemia Cells." Pharmazie 1999, 54, 691-697.

4. Gupton, J.T.; Burnham, B.S.; Krumpe, K.E.; Du, K.; Sikorski, J.A.; Warren, A.E.; Barnes, C.; Hall, I.H. "Synthesis and Cytotoxicity of 2,4-Disubstituted and 2,3,4-Trisubstituted Brominated Pyrroles in Murine and Human Cultured Tumor Cells." Arch. Pharm. Pharm. Med. Chem.. 2000, 333, 3-9.

5. Procopiou, P.A.; Draper, C.D.; Hutson, J.L.; Inglis, G.G.; Ross, B.C.; Watson, N.S. "Inhibitors of cholesterol biosynthesis. 2. 3,5-Dihydroxy-7-(N-pyrrolyl)-6-heptenoates, a novel series of HMGCoA reductase inhibitors." J. Med. Chem. 1993, 36, 3658-3662.

6. Roth, B.D.; Blankley, C.J.; Chucholowski, A.W.; Ferguson, E.; Hoefle, M.L.; Ortwine, D.F.; Newton, R.S.; Sekerke, C.S.; Sliskovic, D.R.; Stratton, C.D.; Wilson, M.W. "Inhibitors of cholesterol biosynthesis. 3. Tetrahydro-4-hydroxy-6-[2-(1H-pyrrol-1-yl)ethyl]-2H-pyran-2-one inhibitors of HMG-CoA reductase. 2. Effects of introducing substituents at positions three and four of the pyrrole nucleus." J. Med. Chem. 1991, 34, 357-366.

7. Jendralla, H.; Baader, E.; Bartmann, W.; Beck, G.; Bergmann, A.; Granzer, E.; von Kerekjarto, B.; Kesseler, K.; Krause, R.; Schubert, W.; Wess, G. "Synthesis and biological activity of new HMG-CoA reductase inhibitors. 2. Derivatives of 7-(1H-pyrrol-3-yl)-substituted-3,5-dihydroxyhept-6(E)-enoic (-heptanoic) acids." J. Med. Chem. 1990, 33, 61-70.

8. Roth BD, Ortwine DF, Hoefle ML, Stratton CD, Sliskovic DR, Wilson MW, Newton RS. "Inhibitors of cholesterol biosynthesis. 1. trans-6-(2-pyrrol-1-ylethyl)-4-hydroxypyran-2-ones, a 
novel series of HMG-CoA reductase inhibitors. 1. Effects of structural modifications at the 2- and 5-positions of the pyrrole nucleus." J. Med. Chem. 1990, 33, 21-31.

9. Bocan, T.M.; Ferguson, E.; McNally, W.; Uhlendorf, P.D.; Bak Mueller, S.; Dehart, P.; Sliskovic, D.R.; Roth, B.D.; Krause, B.R.; Newton, R.S.; "Hepatic and nonhepatic sterol synthesis and tissue distribution following administration of a liver selective HMG-CoA reductase inhibitor, CI-981: comparison with selected HMG-CoA reductase inhibitors." Biochim. Biophys Acta 1992, 1123, 133-144.

10. Watanabe, M.; Koike, H.; Ishiba, T.; Okada, T.; Seo, S.; Hirai, K. "Synthesis and biological activity of methanesulfonamide pyrimidine- and N-methanesulfonyl pyrrole-substituted 3,5dihydroxy-6-heptenoates, a novel series of HMG-CoA reductase inhibitors." Bioorg. Med. Chem. 1997, 5, 437-444.

11. Corsini, A.; Bellosta, S.; Baetta, R.; Fumagalli, R.; Paoletti, R.; Bernini, F. "New insights into the pharmacodynamic and pharmacokinetic properties of statins." Pharmcol. Ther. 1999, 84, 413-428.

12. McKenney, J.M. "Dyslipiemias" In Applied Therapeutics, $7^{\text {th }}$ Ed., Koda-Kimble, M.A.; Young, L.Y., editors; Lippincott Williams and Wilkins: Philadelphia, PA, 2001; pp. 11-1 to 11-43.

13. Takemoto, M.; Liao, J.K. "Pleiotropic effects of 3-hydroxy-3-methylglutaryl coenzyme a reductase inhibitors." Arterioscler. Thromb. Vasc. Biol. 2001, 21, 1712-1719.

14. Shovman, O.; Levy, Y.; Gilburd, B.; Shoenfeld, Y. "Antiinflammatory and immunomodulatory properties of statins." Immunol. Res. 2002, 25, 271-285.

15. Lefer, D.J. "Statins as potent antiinflammatory drugs." Circulation 2002, 106, 2041-2042.

16. Leung, B.P.; Sattar, N.; Crilly, A.; Prach, M.; McCarey, D.W.; Payne, H.; Madhok, R.; Campbell, C.; Gracie, J.A.; Liew, F.Y.; McInnes, I.B. "A novel anti-inflammatory role for simvastatin in inflammatory arthritis." J. Immunol. 2003, 170, 1524-1530.

17. Vega, G.L.; Weiner, M.F.; Lipton, A.M.; Von Bergmann, K.; Lutjohann, D.; Moore, C.; Svetlik, D. "Reduction in Levels of $24 \mathrm{~S}-H y d r o x y c h o l e s t e r o l$ by Statin Treatment in Patients with Alzheimer Disease." Arch. Neurol. 2003, 60, 510-515.

18. Crisby, M.; Carlson, L.A.; Winblad, B. "Statins in the Prevention and Treatment of Alzheimer's Disease." Alzheimer Dis. Assoc. Disord. 2002, 16, 131-136.

19. Austen, B.; Christodoulou G.; Terry, J.E. "Relationship Between Cholesterol Levels, Statins and Alzheimer's Disease in the Human Population." J. Nutr. Health Aging 2002, 6, 377-382.

20. Wolozin, B.; Kellman, W., Rousseau, P.; Celesia, G.G., Siegel, G. "Decreased Prevalence of Alzheimer Disease Associated with 3-Hydroxy-3-methylglutaryl Coenzyme A Reductase Inhibitors." Arch Neurol. 2000, 57, 1439-1443.

21. Kaneko I.; Hazama-Shimda y, Endo A. "Inhibitory effects on lipid metabolism in cultured cells of ML-236B, a potent inhibitor of 3-hydroxy-3-methylglutaryl-coenzyme-A reductase." Eur J. Biochem, 1978, 87, 313-321.

22. Burnham, B.S.; Sood, A.; Tomasz, J.; Powell, W.J.; Spielvogel, B.F.; Chen, S.Y.; Hall, I.H. "The Hypolipidemic Activity of Boronated Nucleosides in Male Mice and Rats." Metal-Based Drugs 1996, 3, 173-183. 
23. Hall, I.H.; Burnham, B.S.; Elkins, A.; Sood, A.; Powell, W.; Tomasz, J.; Spielvogel, B.F. "Boronated Pyrimidines and Purines as Cytotoxic, Hypolipidemic and Anti-inflammatory Agents." Metal-Based Drugs 1996, 3, 155-160.

24. Burnham, B.S.; Chen, S.Y.; Sood, A.; Spielvogel, B.F.; Hall, I.H. "Synthesis and Cytotoxicity of Amine-Borane Adducts of Cyclohexylamines and Toluidines." Pharmazie 1995, 50, 779-783.

25. Burnham, B.S.; Chen, S.Y.; Sood, A.; Spielvogel, B.F.; Hall, I.H. "Hypolipidemic Activity of Amine-Borane Adducts of Cyclohexylamine and Toluidine in Rodents." Metal-Based Drugs 1995, 2, 221-232.

26. Hall, I.H.; Burnham, B.S; Rajendran, K.G.; Chen, S.Y.; Sood, A.; Spielvogel B.F. .; Shaw, B.R. "Hypolipidemic Activity of Boronated Nucleosides and Nucleotides in Rodents," Biomed Pharmacother. 1993, 47, 79-87.

27. Sood, A.; Spielvogel, B.F.; Shaw, B.R.; Carlton, L.; Burnham, B.S.; Hall, E.; Hall, I.H. "The Synthesis and Antineoplastic Activity of 2'-Deoxynucleoside-cyanoboranes in Murine and Human Cultured Cells," Anti-Cancer Research 1992, 12, 335-344.

28. Sood, C.; Sood, A.; Spielvogel, B.F.; Yousef, J.; Burnham, B.; Hall, I. "Synthesis and Antineoplastic Activity of Some Cyano-, Carboxy-, Carbomethoxy-, and Carbamoylborane Adducts of Heterocyclic Amines," J Pharm. Sci. 1991, 80, 1133-1140.

29. Hall, I.H.; Hall, E.S.; Wong, O.T. "The antineoplastic activity of 2,3-dihydrophthalazine-1 ,4dione and $N$-butyl-2,3-dihydrophthalazine-I,4-dione in human and murine tumor cells." AntiCancer Drugs, 1992, 3, 55-

30. Hall, I.H.; Lee, K.H.; Starnes, C.O.; Muraoka, 0.; Sumida, Y.; Waddell, T.G. "Antihyperlipidemic activity of sesquiterpene lactones and related compounds." J. Pharm. Sci. 1980, 69, 694-

31. Simlot, R.; Izydore, R.A.; Wong, O.T.; Hall, I.H. "Synthesis and hypolipidemic activity of 4substituted 1-acyl-1 ,2,4-triazolidine-3,5-dione in rodents." J. Pharmacol Sci. 1993, 82, 408-415.

32. Gupton, J.T.; Krumpe, K.E.; Burnham, B.S.; Webb, T.; Shuford, R.J.; Sikorski, J. "The Application of Vinylogous Imminium Salt Derivatives to a Regiocontrolled and Efficient Relay Synthesis of Lukianol A and Related Marine Natural Products." Tetrahedron 1999, 55, 1451514522.

33. Gupton, J.T.; Krumpe, K.E.; Burnham, B.S.; Dwornik, K.A.; Petrich, S.A.; Du, X.K.; Bruce, M.A.; Vu, P.; Vargas, M.; Keertikar, K.M.; Hosein, K.N.; Jones, C.R.; Sikorski, J.A. "The Application of Disubstituted Vinylogous Iminium Salts and Related Synthons to the Regiocontrolled Preparation of Unsymmetrical 2,3,4-Trisubstituted Pyrroles." Tetrahedron 1998, 45, 5075-5088.

34. Gordon, A.J.; Ford, R.A. The Chemist's Companion: A Handbook of Practical Data, Techniques, and References; John Wiley and Sons: New York, 1972; pp. 429-436.

35. Gupton, J.T.; Krolikowski, D.A.; Yu, R.H.; Sikorski, J.A.; Riesinger, S.W. "Application of 2substituted vinamidinium salts to the synthesis of 2,4-disubstituted pyrroles." J. Org. Chem 1990, $55,4735-4740$. 
36. Gupton, J.T.; Clough, S.C.; Miller, R.B.; Lukens, J.R.; Henry, C.A.; Kanters R.P.F.; James A. Sikorski, J.A. "The application of vinylogous iminium salt derivatives to the synthesis of Ningalin B hexamethyl ether." Tetrahedron, 2003, 59, 207-215

37. Bligh, E.G.; Dyer, W.J. "A rapid method of total lipid extraction and purification." Can. J. Biochem. Physiol. 1959, 37, 911-917.

Sample availability: Contact the authors.

(C) 2004 by MDPI (http:www.mdpi.org). Reproduction is permitted for noncommercial purposes. 